\title{
AN EVALUATION OF HYDROGEN INDUCED CRACKING SUSCEPTIBILITY OF TITANIUM ALLOYS IN US HIGH-LEVEL NUCLEAR WASTE REPOSITORY ENVIRONMENTS
}

\author{
Gopal De, ${ }^{\star}$ Kevin Mon, ${ }^{\natural}$ Gerald Gordon, ${ }^{\uparrow}$ David Shoesmith ${ }^{*}$ and Fred Hua ${ }^{*}$ \\ ${ }^{*}$ Bechtel SAIC Company, LLC \\ ${ }^{\circledR}$ Framatome ANP \\ 1180 Town Center Dr. \\ Las Vegas, NV 89144, USA \\ * Department of Chemistry \\ University of Western Ontario \\ London, ON, N6A 5B7, Canada
}

\begin{abstract}
This paper evaluates hydrogen-induced cracking (HIC) susceptibility of titanium alloys in environments anticipated in the Yucca Mountain nuclear waste repository with particular emphasis on the effect of the oxide passive film on the hydrogen absorption process of titanium alloys being evaluated. The titanium alloys considered in this review include Ti 2, 5, 7, 9, 11, 12, 16, 17, 18, 24 and 29. In general, the concentration of hydrogen in a titanium alloy can increase due to absorption of atomic hydrogen produced from passive general corrosion of that alloy or galvanic coupling of it to a less noble metal. It is concluded that under the exposure conditions anticipated in the Yucca Mountain repository, the HIC of titanium drip shield will not occur because there will not be sufficient hydrogen in the metal even after 10,000 years of emplacement. Due to the conservatisms adopted in the current evaluation, this assessment is considered very conservative.
\end{abstract}

Keywords: Titanium Alloys, Nuclear Waste, Palladium, Ruthenium, and Hydrogen-Induced Cracking

\section{INTRODUCTION}

The Nuclear Waste Policy Act of 1982 (as amended in 1987) designated Yucca Mountain in Nevada as the potential site to be characterized for high-level nuclear waste (HLW) disposal. ${ }^{[1]}$ The 
repository is being designed to include an engineered barrier system that has multiple barrier to groundwater contact with the waste. The center of this engineered barrier system will contain the nuclear waste containers or the waste packages, which will be fabricated from materials that have the potential to resist corrosion under the repository environment for period of at least 10,000 years. Accordingly, the current waste package (WP) design uses a corrosion resistant Ni-based Alloy 22 cylindrical outer barrier surrounding a Type 316 stainless steel inner cylindrical vessel. ${ }^{[2]}$ The waste package is to be covered by a mailbox-shaped drip shield (DS) composed predominantly of Ti 7 with $\mathrm{Ti} 24$ or potentially $\mathrm{Ti} 29$, the ruthenium containing analog of $\mathrm{Ti} 24$, as the structural support material. ${ }^{[2]}$ The WP and DS do not have common failure modes, lending a further safety margin to the repository design.

Numerous studies have evaluated the susceptibility to stress corrosion cracking, and general, localized, galvanic and microbially induced corrosion of Alloy $22^{[3,4,5,6,7,8,9,10,11]}$ and Ti $7 .^{[4,5,11,12,13]}$ The object of this paper is to review the hydrogen induced cracking of titanium alloys under repository relevant exposure conditions. Particular emphasis is given on the effect of the passive film on hydrogen absorption process of titanium and its alloys. Generally, the hydrogen concentration in titanium and its alloys can increase due to the absorption of atomic hydrogen produced from their passive general corrosion or galvanic coupling to a less noble metal. As discussed below, the HIC of titanium drip shield will not occur under repository exposure conditions because there will not be sufficient hydrogen in the metal even after 10,000 years of emplacement. Based on the conservative assumptions made in the current analysis, this assessment can be considered very conservative.

\section{METALLURGICAL ASPECTS OF TITANIUM ALLOYS}

Titanium is an allotropic element, existing as the hexagonal close-packed $\alpha$ phase below $883^{\circ} \mathrm{C}$ and the body-centered cubic $\beta$ phase above $883^{\circ} \mathrm{C} .{ }^{[14]}$ Near $\alpha$-alloys may contain small amounts of the $\beta$-phase in the $\alpha$-matrix. The hydrogen solubility of $\alpha$-titanium is very low $(\sim 20$ to $150 \mathrm{ppm}$ at room temperature) while in the $\beta$-phase it is $>9,000 \mathrm{ppm}^{[15]}$ In $\alpha-\beta$ alloys, the presence of a continuous $\beta$ phase provides fast diffusion paths for atomic hydrogen making them more susceptible to HIC. ${ }^{[16]}$

Relationships between titanium alloys are shown in Figure 1. Chemical compositions and mechanical properties ${ }^{[17]}$ are shown in Tables 1 and 2 . Ti 2, 7, 12, and 16 are $\alpha$-alloys while Ti 524 and 29 are $\alpha-\beta$ alloys. The mechanical properties of Ti 2,7 , and 16 are identical, as are those for Ti 5 and 24 (Table 2). Ti 29 has a bit lower strength than Ti 5 or Ti 24 due to its lower Fe, $\mathrm{O}$ and $\mathrm{N}$ content (Figure 1, Tables 1 and 2). Ti 7 is richer in palladium than Ti 16 (Table 1). For both alloys, the Pd concentration is well below the solubility limit $\left(\sim 1 \mathrm{wt} \% \text { at } 400^{\circ} \mathrm{C}\right)^{[14]}$ and Pd-containing intermetallic compounds are not observed. 


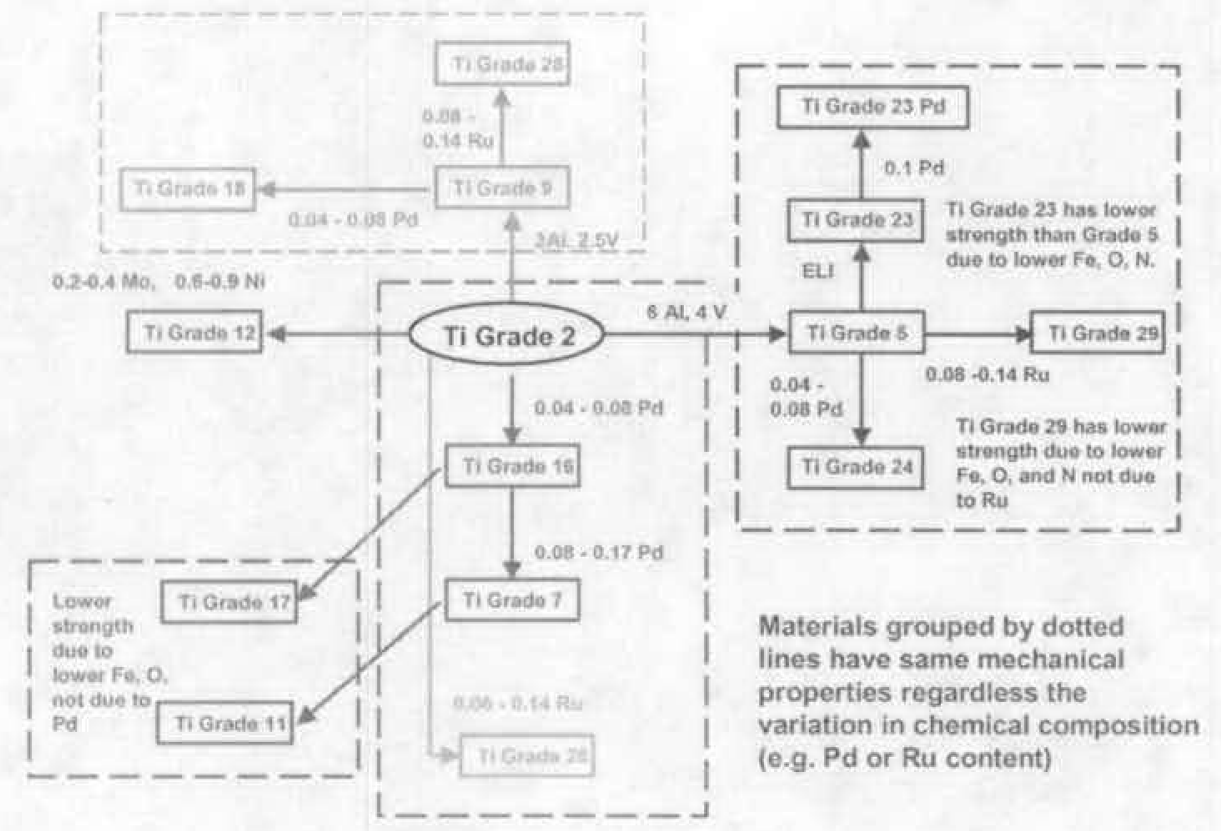

Figure 1. Relationships between titanium alloys. Alloys within dotted lines have same mechanical properties.

Table 1. ASTM specifications for chemical compositions ( $w t \%$ ) of titanium alloys

\begin{tabular}{|c|c|c|c|c|c|c|c|c|c|c|c|c|}
\hline $\begin{array}{l}\text { ASTM } \\
\text { Grade }\end{array}$ & UNS & $\mathrm{N}$ & C & $\mathrm{H}$ & 0 & Fe & Al & v & $\mathrm{Pd}$ & $\mathrm{Ru}$ & $\begin{array}{l}\text { Residual } \\
\text { (each) }\end{array}$ & $\begin{array}{c}\text { Residual } \\
\text { (total) }\end{array}$ \\
\hline Grade 12 & RS3400: & 0.03 & 0.08 & 0.015 & 0.25 & 0.30 & - & - & 7 & & $\begin{array}{c}0.2-0.4 \\
\text { Mo }\end{array}$ & $0.6 .09 \mathrm{Ni}$ \\
\hline Gincle 2 & R50400 & 0.03 & 0.08 & 0.015 & 0.25 & 0.30 & $=$ & + & $=$ & & 0.1 & 0.4 \\
\hline Grade 7 & R52400 & 0.03 & 0.10 & 0.015 & 0.25 & 030 & $=$ & $\cdot$ & $0.12 \cdot 0.25$ & & 0.1 & 0.4 \\
\hline Grade 16 & R52402 & 0.03 & 0.08 & 0.015 & 0.25 & 0.30 & 4 & is & $0.04-0.08$ & & 0.1 & 0.4 \\
\hline Grade 17 & R52252 & 0.03 & 0,08 & 0.015 & 0.18 & 0.20 & $=$ & - & $0.04-0.08$ & & 0.1 & 0.4 \\
\hline Grade 11 & R52250 & 0.03 & 0.10 & 0.015 & 0.18 & 0.20 & $\div$ & 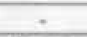 & 0.120 .25 & & 0.1 & 0.4 \\
\hline Grade 5 & RS6400 & 0.05 & 0.08 & 0.015 & 0.20 & 0.40 & $5.5-6.75$ & 3.5 .45 & 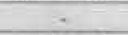 & & 0,1 & 0.4 \\
\hline Grade 24 & RSo405 & 0.05 & 0.08 & 0.015 & 0.20 & 0.40 & $5.5-6.75$ & $3.5-4.5$ & 0.040 .08 & & 0.1 & 0.4 \\
\hline Grade 9 & R56320* & 0.03 & 0,08 & 0.015 & 0.12 & 0.25 & $2.5-3.3$ & $20-3.0$ & 2 & & 01 & 0.4 \\
\hline Grade 18 & R56322 & 0.03 & 0.08 & 0.015 & 0.15 & 0.25 & $2.5-3.5$ & $2.0-3,0$ & $0.04-0.08$ & & 0.1 & 0.4 \\
\hline Grade 26 & R52404 & 0.03 & 0.08 & 0.015 & 0.20 & 0.30 & & & & $0.08-0.14$ & 0.1 & 0.4 \\
\hline Grade 28 & R56923 & 0.03 & 0.08 & 0.015 & 0.15 & 0.25 & $2,5 \cdot 3,5$ & 2.0 .3 .0 & & $0.08-0.14$ & 0.1 & 0.4 \\
\hline Grade 99 & Ra6404 & 0003 & 0.08 & 0.015 & 0,13 & 0.25 & $5.5-6.3$ & $3.5-4.5$ & & $0,08-0,14$ & 0.1 & 0.4 \\
\hline
\end{tabular}

Table 2. ASTM specifications of mechanical properties of titanium alloys ${ }^{[17]}$

\begin{tabular}{|c|c|c|c|c|c|c|c|c|}
\hline \multirow{3}{*}{ Material } & \multirow{3}{*}{ UNS Designation } & \multicolumn{2}{|c|}{$\begin{array}{l}\text { Minimuan Tensile } \\
\text { Strength }\end{array}$} & \multicolumn{4}{|c|}{ Yield Strength, $0.2 \%$ Offset } & \multirow{3}{*}{$\begin{array}{c}\text { Minimum } \\
\text { Elongation in } 2 \text { in. } \\
\%\end{array}$} \\
\hline & & \multirow{2}{*}{ ksi } & \multirow{2}{*}{$\mathrm{MPa}$} & \multicolumn{2}{|c|}{ Min } & \multicolumn{2}{|c|}{ Max } & \\
\hline & & & & ksi & $\mathrm{MPa}$ & ksi & MPa & \\
\hline Grade 12 & R53400 & 70 & 483 & 50 & 345 & - & $=$ & 19 \\
\hline Grade 2 & R.50400 & 50 & 345 & 40 & 275 & 65 & 450 & 20 \\
\hline Grade 7 & R52400 & 50 & 3.45 & 40 & 275 & 65 & 450 & 20 \\
\hline Grade 16 & R5240? & 50 & 345 & 40 & 275 & 65 & 450 & 20 \\
\hline Grade 17 & R52252 & 35 & 240 & 25 & 170 & 45 & 310 & 24 \\
\hline Grade 11 & R52250 & 35 & 240 & 25 & 170 & 45 & 310 & 24 \\
\hline Grade 5 & 1856406 & 130 & 895 & 120 & 828 &. & 5 & 10 \\
\hline Grade 24 & R56405 & 130 & 895 & 120 & 828 & - & 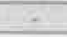 & 10 \\
\hline Grade 9 & $\mathrm{R} 56320^{\circ}$ & 90 & 620 & 70 & 483 &. & - & 15 \\
\hline Grade 18 & R56322 & 90 & 620 & 70 & 483 & $\cdot$ & - & 15 \\
\hline Grade 26 & R52404 & 50 & 345 & 40 & 275 & 65 & 450 & 20 \\
\hline Grade 28 & R56323 & 90 & 620 & 70 & 483 & + & 1. & 15 \\
\hline Giade 29 & RS56404 & 120 & 828 & 110 & 750 & 4 &. & 10 \\
\hline
\end{tabular}




\section{HYDROGEN UPTAKE BY TITANIUM ALLOYS}

Small ionic size makes hydrogen atoms very well suited for dissolution in solid titanium alloys. - Yet there is a solubility limit for hydrogen in titanium and its alloys. Consequently, if atomic hydrogen diffusion into a titanium alloy is continued even after the hydrogen solubility limit of that alloy is reached, brittle titanium hydride phase(s) will start precipitating out. These hydride precipitates can enhance the HIC of titanium alloys at lower applied stresses. At higher applied stress levels, however, an alternative failure mechanism can be operative. An increase in hydrogen-assisted localized plasticity at the crack tip where the presence of hydrogen reduces the stress required for plastic flow, and enhanced mobility of dislocations. ${ }^{[18,[19]}$ can promote the HIC of titanium alloys at high applied stresses. The following three conditions are required to exist simultaneously for the HIC or hydrogen embrittlement of $\alpha$ titanium alloys to occur:

- $\quad$ surface hydrogen generation,

- temperatures above approximately $80^{\circ} \mathrm{C}$, so that the hydrogen diffusion rate becomes significant, and

- $\quad$ solution $\mathrm{pH}<3$ or $>12$, or impressed potentials $<-0.7 \mathrm{~V}_{(\mathrm{SCE}) \cdot}{ }^{[19]}$

A review of the scientific literature reveals that some alloying additions to titanium metal significantly enhances its corrosion resistance in reducing acid environment ${ }^{[20,21]}$ by electrochemical means, such as depolarizing the cathode (i.e., cathodic modification) and increasing the anodic Tafel slope. ${ }^{[21]}$ The platinum group metals (PGM), due to their low hydrogen overpotential and accelerated hydrogen ion reduction kinetics in acid solutions, are ideal alloying additions for titanium. ${ }^{\text {[22] }}$ However, they may also serve as pathways for hydrogen absorption. For example, intermetallic particles, not covered by a passive film, could act as "hydrogen windows" in the oxide. Key alloying elements in $\alpha$-Ti alloys, such as $\mathrm{Ni}, \mathrm{Pd}$ and $\mathrm{Ru}$ not only facilitate proton reduction, but also possess a significant solubility for hydrogen. ${ }^{[23]}$

\section{The Role of the Passive Film in Retarding Hydrogen Absorption}

A defect free oxide film on titanium alloys should be impervious to hydrogen. For hydrogen absorption to occur, it is necessary to induce redox transformations $\left(\mathrm{Ti}^{4+} \rightarrow \mathrm{Ti}^{3+}\right.$ ) within the oxide or the opening of "hydrogen windows" at intermetallic sites. This requirement accounts for the threshold potential of $<-0.7 \mathrm{~V}_{\text {(SCE) }}$ specified by Schutz and Thomas ${ }^{[19]}$ and demonstrated in electrochemical measurements by Murai et al. ${ }^{[2]}$ (see Figure 2(a)). Figure 2(b) illustrates the parallel oxide redox transformation-hydrogen absorption process, which occurs at potentials sufficiently negative of the flatband potential for establishing surface degeneracy in the oxide. ${ }^{[25]}$ At these potentials, titanium hydrides are thermodynamically stable ${ }^{[26,27]}$ and the passive film can act as a transport barrier. 


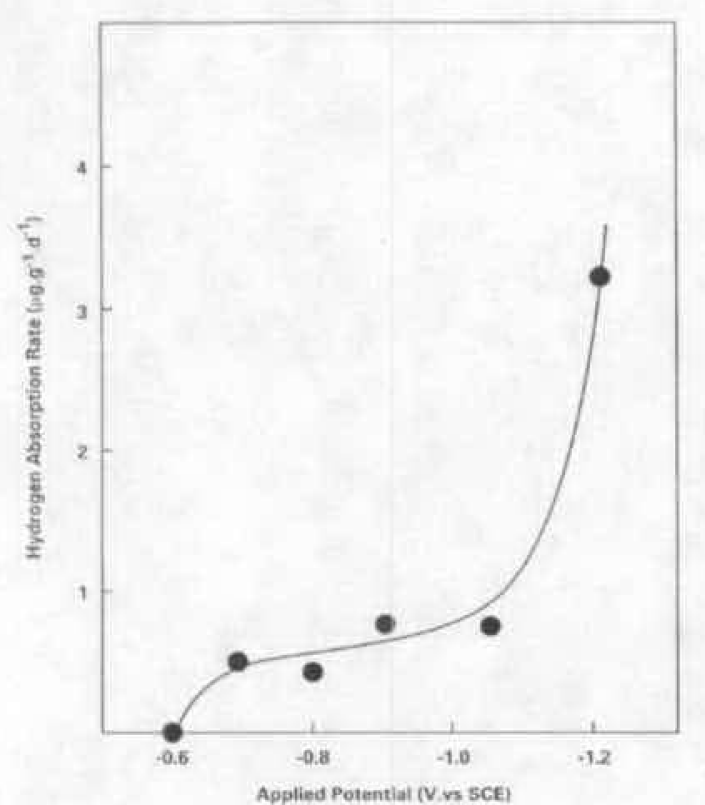

(a)

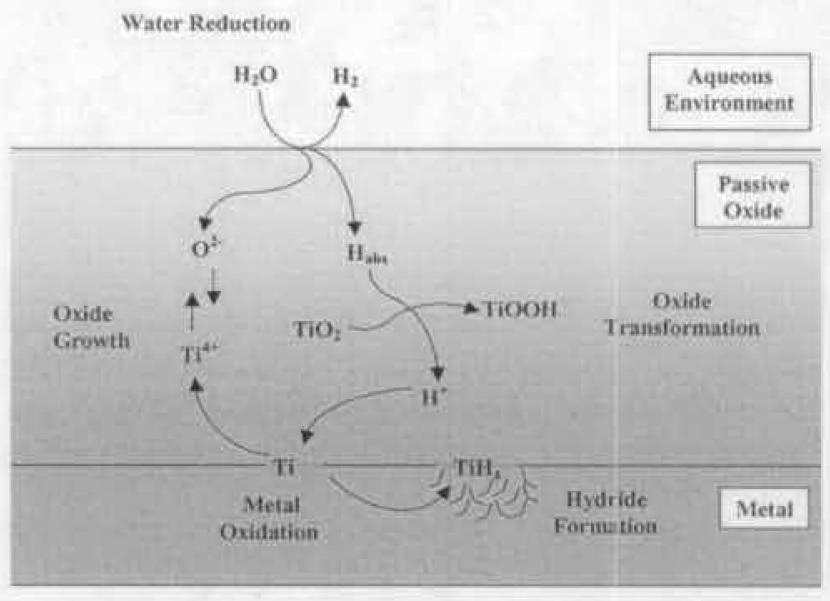

(b)

Figure 2. Hydrogen absorption rate versus applied potential for $\mathrm{Ti} 2$ (a) ${ }^{[24]}$ and a schematic of cathodic transformations which lead to the absorption of hydrogen $(b)^{[44]}$

The tendency for alloyed Pd to accelerate hydrogen absorption into titanium is suppressed when a passive oxide is present (i.e., at $\mathrm{pH} \geq 4$ ). ${ }^{[28]}$ The rate of hydrogen absorption decreases parabolically with exposure time even under cathodically polarized conditions when hydrogen absorption would be expected to be accelerated. ${ }^{[29,30,31]}$. This indicates that surface absorption sites become saturated and the rate of absorption will be controlled by the rate of diffusive transport. For $\alpha$ alloys, diffusive transport is very low. Thermally grown oxides are known to suppress hydrogen absorption in aggressive brine environments $(6 \% \mathrm{NaCl})$ up to temperatures of $120^{\circ} \mathrm{C}^{[32]}$ Hydrogen absorption in deaerated $\mathrm{HCl}\left(2 \leq \mathrm{pH} \leq 4 ; 50^{\circ} \mathrm{C}\right.$ to $\left.250^{\circ} \mathrm{C}\right)$ is significant but it is negligible under aerated conditions, ${ }^{[33]}$

Hydrogen absorption by Ti 12 is more efficient due to the presence of the Ni-stabilized $\beta$-phase and $\mathrm{Ti}_{2} \mathrm{Ni}$ precipitates which catalyze proton reduction and have a high solubility for hydrogen. According to Shoesmith and King, ${ }^{[34]}$ the oxide films on Ti 12 in the experiments of Kim and Oriani [30,31] are highly defective, almost certainly a consequence of the $\mathrm{Mg}^{2+}$ content in the brines used and hydrogen absorption is to be expected. However, despite the fact that corrosion continued unabated, the rate of hydrogen absorption still decreased with time, suggesting that, for very long exposure times, it would become negligible.

\section{Enrichment of Alloying Elements on Titanium Surface}

For Ti 12 (alloyed with $\mathrm{Ni}$ and Mo), Ti 7 and 16 (alloyed with Pd), and Ti-Ru alloys, such as Ti 29 , it has been proposed that corrosion in acidic environments in the absence of a passive oxide leads to the release of alloying elements which subsequently redeposit to produce sites that act as proton reduction catalysts. $[35,36,37,38,39,40]$ Depolarization of proton reduction at these sites then shifts the potential to more positive values thereby re-enforcing passivity. For $\mathrm{Ti} 12$, an alternative explanation has been proposed ${ }^{[41,42]}$ in which $\mathrm{Ni}$ is localized in $\mathrm{Ti}_{2} \mathrm{Ni}$ intermetallics which act as catalytic cathodes galvanically-coupled to the surrounding Ti $\alpha$-grains to similarly re-enforce passivity, a scenario supported by analytical evidence for the presence of $\mathrm{Ni}^{2+}$ in solution during passive corrosion in strong 
acidic solutions. Since, only marginal amounts of alloying elements have been detected in solution during corrosion of Ti-Pd alloys ${ }^{[35]}$ or Ti-Ru alloys, ${ }^{[43]}$ this last mechanism seems unlikely for these materials.

For Pd-containing alloys, there is a possibility that Pd causes anodic ennoblement due to either metal dissolution or oxide growth. In both cases, preferential oxidation of Ti would lead to enrichment of $\mathrm{Pd}$ in the surface of the alloy, and hence to its ennoblement, as illustrated in Figure 3 . $^{[25]}$

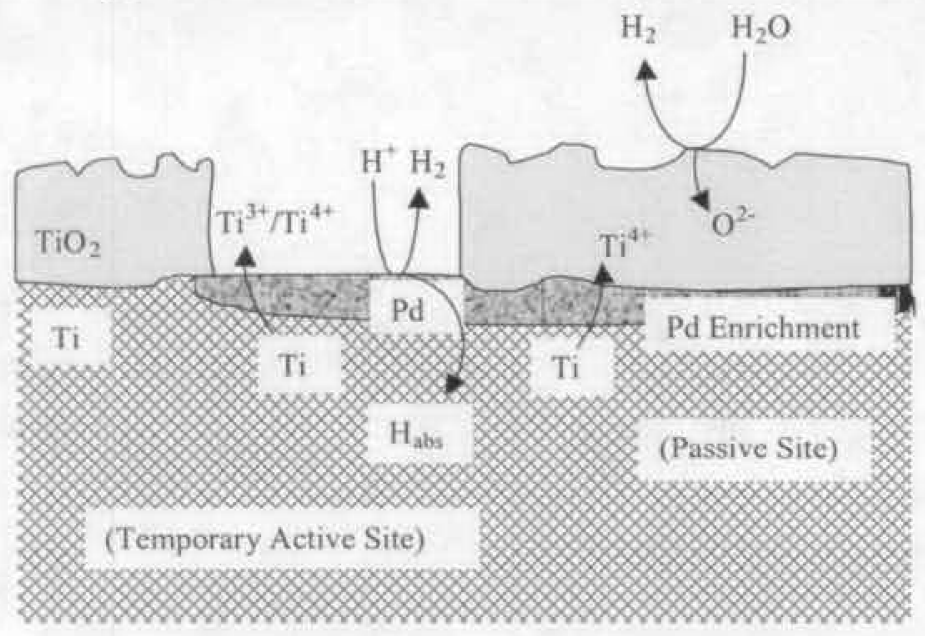

Figure 3. Schematic illustrating the anodic ennoblement of a Pd-containing Ti-alloy due to surface enrichment by $\mathrm{Pd}$ at temporarily active or passive sites ${ }^{[44]}$

In support of this ennoblement mechanism is the analytical evidence for the accumulation of $\mathrm{Pd}$ in the surface of Pd-containing alloys during corrosion in acid solutions. ${ }^{[45]}$ Whether this is due to the redeposition of dissolved $\mathrm{Pd}^{2+}$ or the accumulation of $\mathrm{Pd}$ or $\mathrm{Pd}$-containing particles after the preferential dissolution of $\mathrm{Ti}$ is unclear, ${ }^{[4,46]}$ but the latter seems more probable.

\section{Threshold Potential for Hydrogen Reduction and Absorption}

Pure titanium dioxide film is an insulator until the solid state reduction of $\mathrm{Ti}^{4+} \rightarrow \mathrm{Ti}^{3+}$ in the oxide occurs, when the film becomes conductive and it is possible to transfer electrons from hydrogen atoms absorbed in the oxide. In acid solutions the reduced film can dissolve since $\mathrm{Ti}^{3+}$ is much more soluble than $\mathrm{Ti}^{4+}$. Significant cathodic polarization (either by galvanic coupling to carbon steel or application of potential) is required for these transformations to occur. There is ample evidence that significant hydrogen transport through the film can occur only at potentials $<-1.0 \mathrm{~V}_{(\mathrm{SCE})}{ }^{[47,48,49]}$ Using an electrochemically controlled bilayer system comprised of a layer of $\mathrm{TiO}_{2}$ deposited on $\mathrm{Pd}$ metal, Pyun and Yoon ${ }^{[48]}$ showed no detectable hydrogen transport through the $\mathrm{TiO}_{2}$ layer into the $\mathrm{Pd}$ occurred until the potential applied was $<-1.0 \mathrm{~V}_{\text {(SCE) }}$ (Figure 4 (a)). In the cathodic polarization studies of Noël et al. ${ }^{[49]}$ on $\mathrm{Ti} 2$, $\mathrm{Ti} 12$, and $\mathrm{Ti} 16$ in acidic solutions at $95^{\circ} \mathrm{C}$, Figure 4 (b), the amount of hydrogen absorbed as a function of applied potential was measured. The hydrogen absorption behavior can be separated into two distinct regions, denoted $\mathrm{A}$ and $\mathrm{B}$ in the figure. In region $\mathrm{A}\left(>-0.6 \mathrm{~V}_{\text {(SCE) }}\right.$ ), no hydrogen absorption into the metal was observed, while for more negative potentials in region B it was. This observation is consistent with the demonstrated existence of a hydrogen absorption threshold of $\sim-0.6 \mathrm{~V}_{\text {(SCE) }}{ }^{[24]}$ discussed above (Figure 2 (a)). 


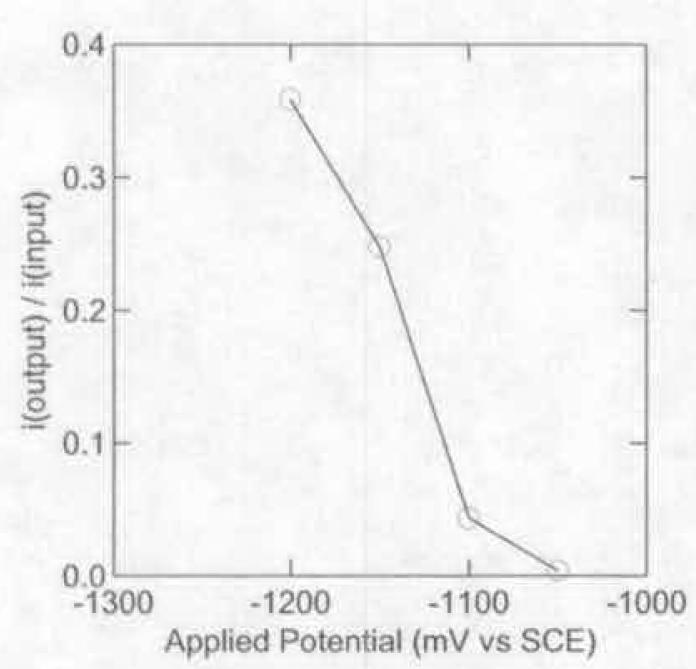

(a)

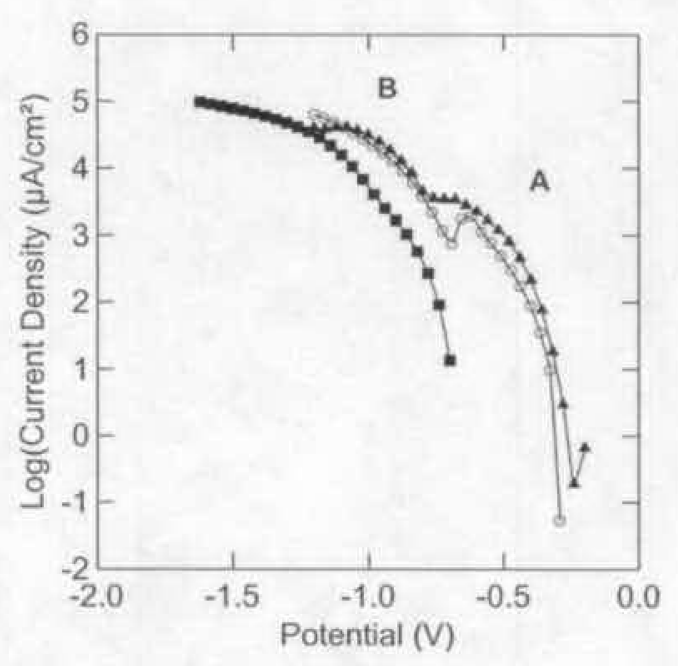

(b)

Figure 4. The ratio of the input current to output current as a function of the potential applied across a $\mathrm{TiO}_{2}$ layer deposited on $\mathrm{Pd}(\mathrm{a})^{[48]}$ and potentiostatically recorded polarization curves for $\mathrm{Ti} 2 \mathrm{in} 0.1 \mathrm{~mol} / \mathrm{L}$ $\mathrm{HCl}+0.27 \mathrm{~mol} / \mathrm{L} \mathrm{NaCl}$ at $95^{\circ} \mathrm{C}(\mathrm{b}) .^{[49]}$

\section{Effects of Palladium on Hydrogen Absorption}

For proton reduction on non-palladium-containing alloys (e.g., Ti 2) in acidic solutions, a cathodic Tafel slope of $>120 \mathrm{mV} /$ decade is obtained. In acidic solutions, the threshold potential is that at which the $\mathrm{TiO}_{2}$ film is reduced and dissolves as $\mathrm{Ti}^{3+}$ and the cathodic Tafel slope is consistent with rate control by the proton discharge step on the non catalytic exposed Ti surface. ${ }^{[23,24,50]}$ Fukuzuka et al. $^{[51]}$ showed that enhanced proton reduction under similar conditions was possible at much lower applied potentials on $\mathrm{Pd}$-containing alloys than on $\mathrm{Ti} 2$, and that there was a distinct correlation between alloy corrosion rate and hydrogen absorption rate in boiling $\mathrm{HCl}$, as shown in Figure 5 .

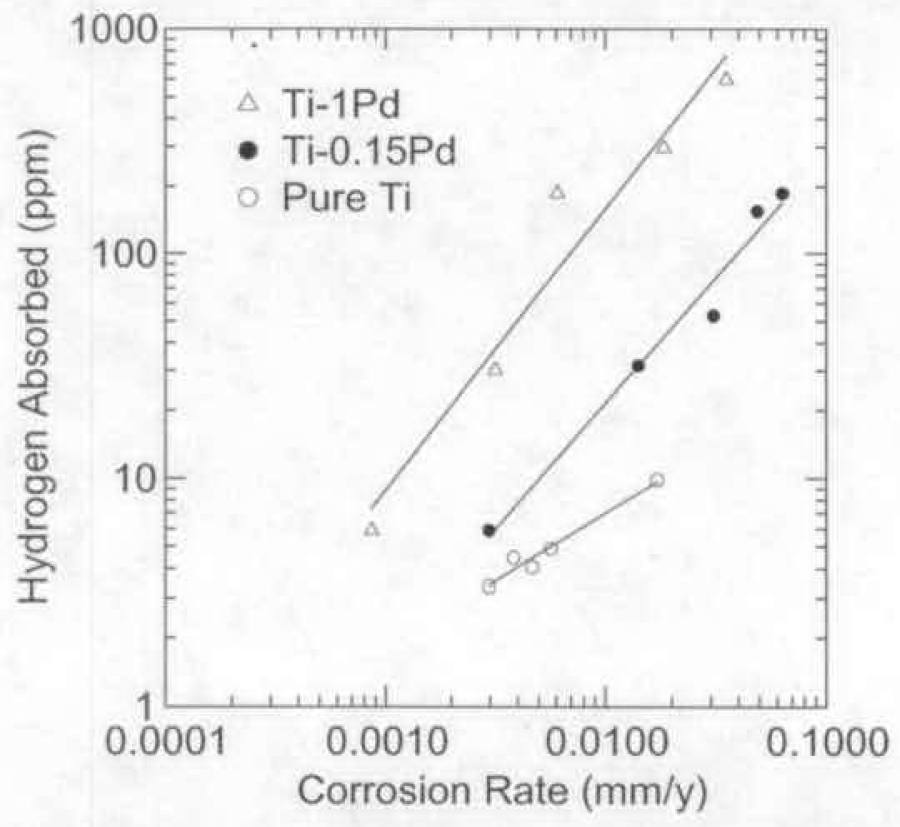

Figure 5. Relationship between the amount of hydrogen absorbed and the corrosion rate of $\mathrm{Ti}(\mathrm{c})$ and titanium containing $1 \% \operatorname{Pd}(\Delta)$ and $0.15 \% \operatorname{Pd}(\bullet)^{[51]}$ 
For Pd-containing materials, proton reduction occurs at much lower potentials and with much smaller cathodic Tafel slopes $(50-65 \mathrm{mV} /$ decade), indicating control of the overall proton reduction reaction by the electrochemical desorption step. This is consistent with the catalytic behavior observed on noble metals such as Pd. ${ }^{[23]}$ Schutz and Xiao ${ }^{[50]}$ observed similar effects for proton reduction on $\mathrm{Ti}$ 2 compared to $\mathrm{Ti} 7$ and $\mathrm{Ti}$ 16. The cathodic Tafel slope for Ti $16(100 \mathrm{mV} /$ decade $)$ was larger than that obtained for $\mathrm{Ti} 7(80 \mathrm{mV} /$ decade $)$ indicating that the ability to catalyze proton reduction decreases as the Pd content of the titanium decreases. These results are consistent with those of Fukuzuka et al. [51] showing that enhanced proton reduction was possible at much lower applied potentials on Pdcontaining alloys than on $\mathrm{Ti} 2$ (Figure 5). This observation of catalyzed proton reduction at less negative potentials suggests that the need for redox transformations in the oxide is not a prerequisite for proton reduction.

For the Pd-containing alloys, the formation of $\beta$-phase is negligible and intermetallic particles, when present, appear to be inert to corrosion. ${ }^{[52,53]}$ Under acidic conditions, the rate and efficiency of hydrogen absorption increases with increasing $\mathrm{Pd}$ content, though, in the absence of any apparent separation of the $\mathrm{Pd}$ into discrete intermetallics, the mechanism of absorption remains unclear. Presumably, in the absence of separated intermetallic particles, the discharge step, and the subsequent hydrogen absorption step, are catalyzed at the atomic level.

For $\mathrm{Ti} 16$, hydrogen absorption was not observed for applied potentials as low as $-1.0 \mathrm{~V}$, despite the presence of a large number of randomly dispersed intermetallic particles. ${ }^{[54,55]}$ Since the material investigated contained a substantial amount of $\mathrm{Fe}$ (as an impurity) and it is likely that the intermetallic particles also contain Fe. However, since they are apparently inert to corrosion in acidic solutions, there is a possibility that $\mathrm{Pd}$ co-segregated to yield TiPdFe particles. The composition and properties of these particles remain to be elucidated. A possible reason for the lack of hydrogen absorption by the intermetallic particles is that the experiments of Ikeda and Quinn ${ }^{[54,55]}$ were conducted in neutral solutions when a passive oxide, impermeable to hydrogen, may have been present on these particles.

Experimental evidence for the enhancement for hydrogen absorption due to Pd addition is not conclusive. While concerns exist that alloying Pd with titanium might promote hydrogen absorption into the metal, ${ }^{[56]}$ other investigators showed that Ti-Pd alloys are not necessarily sensitive to hydrogen absorption. ${ }^{[51,57]}$ For instance, Fukuzuka et al. ${ }^{[51]}$ demonstrated that, while the hydrogen absorption efficiency of Ti-Pd alloys increased with an increase in $\mathrm{Pd}$ content in deaerated $\mathrm{HCl}$, both the corrosion rate and hydrogen absorption efficiency were decreased when the $\mathrm{HCl}$ was aerated. This influence of aeration was attributed to the ennoblement of the corrosion potential, on addition or increase in content of $\mathrm{Pd}$, and to the low over-voltage of oxygen reduction, which may compete with proton reduction. ${ }^{[21]}$

\section{Effects of Other Alloying Additions and Impurities}

A common impurity in titanium alloys is Fe. Watanabe et al. ${ }^{[58]}$ showed that when the $\mathrm{Fe}$. concentration exceeds the $\sim 0.035 \mathrm{wt} . \%$ solubility limit, $\mathrm{Ti}_{\mathrm{x}} \mathrm{Fe}$ particles are formed. However, studies of the influence of $\mathrm{Fe}$ on hydrogen absorption by titanium alloys have yielded conflicting results. $[59,60$,

61] For instance, Fe present in $\beta$-phase leads to enhanced corrosion of $\mathrm{Ti} 2^{\left[{ }^{[62]}\right.}$ and $\mathrm{Ti} 12 .^{[63]} \mathrm{By}$ contrast, when $\mathrm{Fe}$ is present as $\mathrm{Ti}_{\mathrm{x}} \mathrm{Fe}$ intermetallics, corrosion rates decreased and passivity was easier to maintain. While the intermetallic $\mathrm{Ti}_{\mathrm{x}} \mathrm{Fe}$ has been shown to be a hydrogen absorber, it is difficult to activate for hydrogen storage. ${ }^{[64]}$ The hydride formed on $\mathrm{Ti}_{\mathrm{x}} \mathrm{Fe}$ possesses less lattice distortion than that formed on $\alpha$-Ti. Since this feature is claimed to retard the diffusion of hydrogen, ${ }^{[64]} \mathrm{Hence} \mathrm{Ti}_{\mathrm{x}} \mathrm{Fe}$ could actually impede hydrogen absorption. 
It is likely that absorbed hydrogen atoms would remain localized at intermetallic sites in $\alpha$ phase alloys. If $\beta$-phase ligaments co-exist, then enhanced transport of hydrogen into the bulk could occur. In the absence of $\beta$-phase ligaments, the intermetallic particles may become saturated with hydrogen, and the efficiency of further hydrogen absorption approaches zero. In Ti 12 , the high hydrogen solubility of $\mathrm{Ti}_{2} \mathrm{Ni}$ and the $\beta$-phase, and $10^{5}$ times higher diffusion rate of hydrogen in the $\beta$ phase, than in the $\alpha$-phase, as reported by Wang et al., ${ }^{[65]}$ facilitates hydrogen transport into the bulk of the alloy. This process is illustrated in Figure 6(a). Figure 6(b) illustrates how such a "hydrogen window" could lead to more efficient hydrogen absorption than expected on a passive surface.
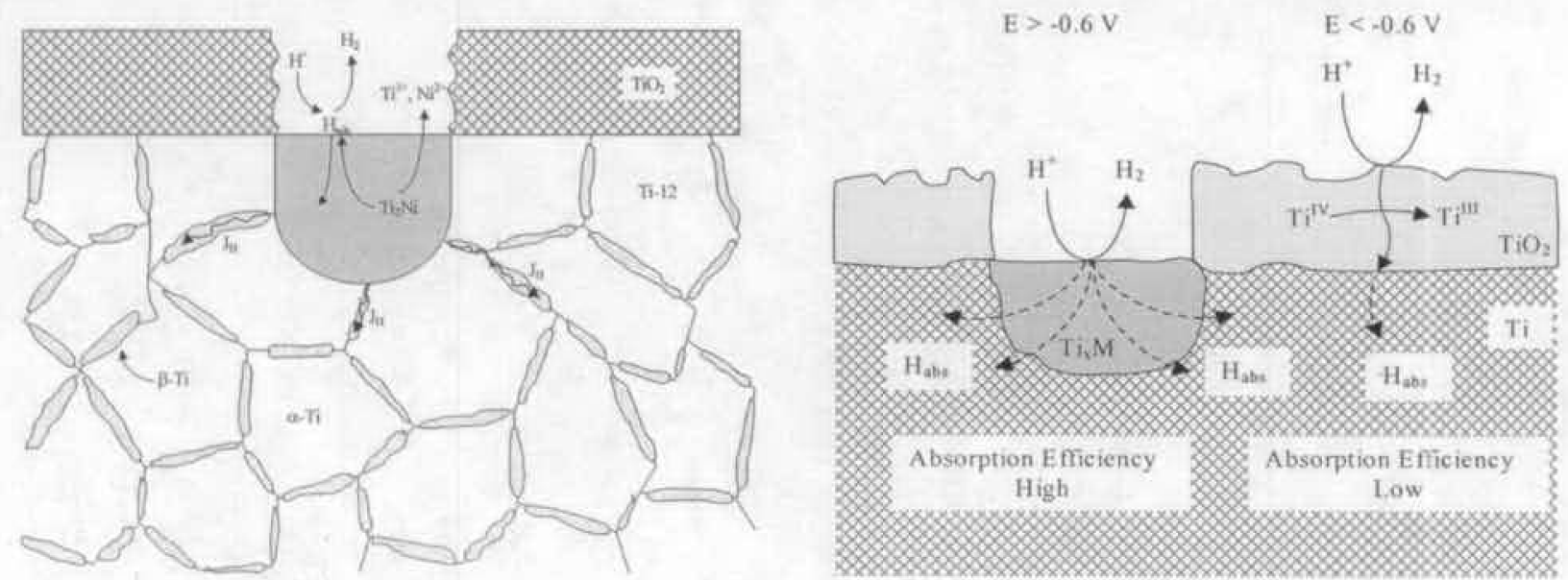

Figure 6.

Schematic illustrating how the corrosion of a $\mathrm{Ti}_{2} \mathrm{Ni}$ intermetallic particle can lead to the absorption of hydrogen and how the presence of $\beta$-phase ligaments along $\alpha$-phase grain boundaries can assist the transport of this absorbed hydrogen into the bulk of the alloy $(a)^{[44]}$ schematic illustrating the low efficiency of hydrogen absorption under passive conditions and the possibility of a much more highly efficient absorption process through catalytic intermetallic windows in the passive oxide (b). . $^{44]}$

To explain the absence of hydrogen absorption in $\mathrm{Ti} 16$ until applied potentials are < $1.0 \mathrm{~V}_{\text {(SCE), Ikeda and Quinn }}{ }^{[55]}$ argue that intermetallic particles can act as point conductors within an insulating $\mathrm{TiO}_{2}$ oxide. At cathodic potentials, the low resistance to current flow at these sites prevents polarization of the surrounding oxide, and the potential at the intermetallic must reach $-1.0 \mathrm{~V}_{\text {(SCE) }}$ before a potential of $-0.6 \mathrm{~V}_{(\mathrm{SCE})}$ is applied across the oxide. For the prevention of $\mathrm{H}$ absorption into the alloy, the cathodic intermetallics must either be unable to absorb $\mathrm{H}$ or be saturated with $\mathrm{H}$ so that its hydrogen absorption efficiency becomes zero. For behavior in the latter mode, the intermetallics would be acting as hydrogen storage sites, which in the absence of any $\beta$-phase in the bulk of the alloy, retains the hydrogen at the surface of the alloy. Since they are small in volume and few in number, their hydrogen content may be undetectable by bulk analyses.

Shoesmith et al. ${ }^{[52]}$ and Noel ${ }^{[53]}$, by conducting impedance study on Ti 2, 12, and 16 in neutral $0.27 \mathrm{~mol} / \mathrm{L} \mathrm{NaCl}$ as a function of temperature (ambient to $80^{\circ} \mathrm{C}$ ), concluded that, as the temperature increases, Ti 12 develops corrosion sites at the bottom of relatively narrow, highly resistive pores. By contrast, the sites at the bottom of relatively open pores/faults in $\mathrm{Ti} 16$ remain inert over the whole temperature range. It was concluded that the intermetallic particles in $\mathrm{Ti} 16$ are inert. For $\mathrm{Ti} 12$, 
however, the reactive sites coincide with the location of $\mathrm{Ti}_{2} \mathrm{Ni}$ intermetallic particles or reactive $\beta$ phase in the underlying $\alpha$-Ti matrix. A similar susceptibility to corrosion has been demonstrated for $\beta$ phase $\mathrm{Ti}$ when its Ni content is high. ${ }^{[66]}$

\section{CORROSION AND HYDROGEN ABSORPTION}

\section{Corrosion of Ti Drip Shield under Repository Conditions}

Of primary concern to the potential hydrogen-induced cracking of drip shield materials is a combination of enhanced passive corrosion under alkaline conditions, accompanied by hydrogen absorption at sites exposed to seepage. The prospect for the initiation of crevice corrosion is remote with either $\mathrm{Ti} 7$ or $\mathrm{Ti} 24$, since Schutz ${ }^{[20]}$ has tested the corrosion resistance of $\mathrm{Ti} 24$ in the same aggressive environments used for $\mathrm{Ti} 7$ and found this alloy to be as resistant to crevice corrosion as $\mathrm{Ti}$ 7.

Under general corrosion conditions, especially in the presence of oxygen as at Yucca Mountain, passive conditions prevail, as reflected in positive corrosion potentials measured in repository relevant environments. This will preclude significant hydrogen absorption by either Ti 7 or $\mathrm{Ti} 24$ since the corrosion potential is too positive to allow the redox transformations in the oxide required for the film to become permeable to hydrogen. Also, under oxidizing conditions, any exposed noble metal-containing intermetallic particles in the alloy will be passivated, and their catalytic properties for proton reduction and hydrogen absorption will be reduced.

Blackwood et al. ${ }^{[67]}$ found the rate of passive film dissolution in $1.0 \mathrm{~mol} / \mathrm{L} \mathrm{KOH}$ at $45^{\circ} \mathrm{C}$ to be about $3 \mathrm{~nm} / \mathrm{hr}(\sim 26 \mu \mathrm{m} / \mathrm{yr})$. This is comparable to the rate in $3 \mathrm{~mol} / \mathrm{L} \mathrm{H}_{2} \mathrm{SO}_{4}(2.23 \mathrm{~nm} / \mathrm{hr})$. If the same $\mathrm{pH}$ dependence prevails in both alkaline and acidic solutions, this rate would decrease by about an order of magnitude for each unit decrease in $\mathrm{pH}$. Available results suggest the presence of fluoride will not exert a major influence on the passive corrosion rate in alkaline solutions. ${ }^{[68,69]}$ This is supported by experiments on dental alloys ${ }^{[68]}$ and in flue gas scrubber environments ${ }^{[69]}$ which indicate no influence of fluoride for $\mathrm{pH} \geq 3.5$, and $\mathrm{X}$-ray photoelectron spectroscopic (XPS) evidence on passive $\mathrm{Ti}$ specimens at high $\mathrm{pH}$ shows no incorporation of $\mathrm{F}^{-}$into the passive film. ${ }^{[70]}$

While the passive corrosion rate of $\mathrm{Ti}$ increases in alkaline solutions, the above evidence does not clarify whether the films themselves are more or less permeable to hydrogen than they are in neutral and acidic solutions. Voltammetric experiments in $1.0 \mathrm{~mol} / \mathrm{L} \mathrm{NaOH}$ indicate that the redox transformation in the oxide $\left(\mathrm{Ti}^{4+}\right.$ to $\left.\mathrm{Ti}^{3+}\right)$, necessary for hydrogen absorption to occur and for the oxide to become permeable to hydrogen transport, commences for $E \leq-0.6 \mathrm{~V}_{(\mathrm{SCE})} .{ }^{\left[{ }^{[1]}\right.}$ This is approximately the same as in neutral solutions. This coincidence suggests the redox transformation is determined by the solid oxide properties and is independent of the oxide/solution interfacial properties. The former would be expected to be independent, and the latter dependent, on $\mathrm{pH}$. Based on the industrial guidelines proposed by Schutz and Thomas, ${ }^{[19]}$ if aqueous conditions can be achieved on the drip shield surface for $\mathrm{T}<125^{\circ} \mathrm{C}$ then a $\mathrm{pH} \geq 13$ would be required before significant hydrogen absorption could occur. If the drip shield surface temperature were lower, then $\mathrm{pH}>14$ would be required. More conservative limits of $\mathrm{pH}>12$ and $\mathrm{T} \geq 80^{\circ} \mathrm{C}$ were proposed by Schutz. ${ }^{[72]}$ The early evidence of Covington ${ }^{[32]}$ showed that the hydriding of Ti was difficult to achieve unless the surface was abraded or sandblasted, even when galvanically coupled to $\mathrm{Al}$ in boiling simulated seawater, or after attempts to cathodically charge at $\mathrm{pH}=14$. Absorption did occur in $>10 \% \mathrm{NaOH}$. Phillips et al. ${ }^{[73]}$ observed a decrease in the extent of hydrogen absorption with increasing $\mathrm{pH}$ and, over a 50 hour period, the 
amount absorbed for $\mathrm{pH} \geq 10$ was immeasurably small. However, if the surface was abraded then absorption was observed at $\mathrm{pH}=14$ (over a 24 hour period). For pickled and vacuum annealed specimens, no absorption was observed above $\mathrm{pH} \sim 8$. Subsequent aging of abraded specimens prior to application of the galvanostatic charging current led to a decrease in the absorption rate, and prolonged aging removed any influence of abrading. An experiment conducted at $\mathrm{pH}=13$ on Ti 12 at an applied potential of $-1.05 \mathrm{~V}$ at $80^{\circ} \mathrm{C}$ showed no hydride formation. ${ }^{[74}$

Also, there are other factors to impede hydrogen absorption under repository conditions. For example, thermal oxidation has been shown to suppress corrosion and impede hydrogen absorption. ${ }^{[75}$, 76] Generally, such inhibition is noted for films grown thermally for short periods at high temperatures $\left(>400^{\circ} \mathrm{C}\right)$. However, similar retardation may be achievable for films grown over many hundreds of years at the lower repository exposure temperatures $\left(200^{\circ} \mathrm{C}\right.$ to $\left.100^{\circ} \mathrm{C}\right)$. Lunde and Nyborg ${ }^{[74]}$ reported that hydrogen absorption was suppressed, but not eliminated, in hot seawater by the build-up of insoluble scale deposits, which are also likely to accumulate under repository conditions.

It is clear that pitting will not be a failure mechanism and that active crevice corrosion is unlikely for the titanium alloys chosen for the drip shield construction. ${ }^{[70]}$ Thus, in the absence of active crevice corrosion, the most likely corrosion scenario for $\mathrm{Ti}$ under repository conditions is hydrogen absorption in occluded areas existing under surface deposits. For this to happen, the Ti, or at least the intermetallics within it, must function as cathodes coupled to some anode within the system. Hydrogen absorption due to passive general corrosion, crevice corrosion, and galvanic coupling are discussed in the following sections.

\section{Hydrogen Absorption During Passive General Corrosion}

The structure of passive oxide layers formed on a titanium surface over long exposure periods has been analyzed by several investigators. ${ }^{[77,78]}$ Over a 6-year exposure period to water-saturated bentonite clay at $95^{\circ} \mathrm{C}$, the maximum dissolution rate was $<0.4 \mathrm{~nm} /$ year. For more acidic conditions, Blackwood et al. ${ }^{[67]}$ measured dissolution rates of passive titanium oxides using electrochemical methods that determined the amount of oxide removed from the metal surface rather than by attempting to measure the amount of dissolved $\mathrm{Ti}^{3+} / \mathrm{Ti}^{4+}$ in solution. These rates were measured in acidic sulphate, perchlorate, phosphate, and chloride solutions at $45^{\circ} \mathrm{C}$ and, generally over the $\mathrm{pH}$ range 0 to 2 . Extrapolation of the corrosion rates according to the observed $\mathrm{pH}$ dependence predicts negligibly small dissolution rates in neutral solutions, consistent with the observations of Mattsson and co-workers ${ }^{[77,78]}$ and the results obtained in the Yucca Mountain Project's Long Term Corrosion Test Facility (LTCTF). ${ }^{[79]}$

According to Shoesmith et al., ${ }^{[80]}$ under passive waste disposal conditions, direct absorption of hydrogen produced by water radiolysis and absorption of atomic hydrogen produced by corrosion are the two processes by which hydrogen could be produced, and possibly absorbed. The direct absorption of radiolytically-produced hydrogen does not appear to be significant except at a combination of high dose rates $\left(>10^{2} \mathrm{~Gy} / \mathrm{h}\right)$ and high temperatures $\left(>150^{\circ} \mathrm{C}\right) .{ }^{[80]}$ This combination is clearly unattainable under Yucca Mountain drip shield conditions, leaving the corrosion process as the only feasible source of hydrogen for absorption. Under passive conditions, the corrosion potential for passive titanium must reside at a value at which water reduction can couple to titanium oxidation, and, hence, must be at, or more negative than, the thermodynamic stability line for water. At such potentials, titanium hydrides are thermodynamically stable with respect to the metal. Consequently the passive film can be considered only as a transport barrier and not as an absolute barrier. The rate of hydrogen absorption at the corrosion potential will be controlled by the rate of the corrosion reaction, which dictates the rate 
of production of absorbable hydrogen, providing the basis for modeling HIC discussed later in this paper.

\section{Hydrogen Absorption During Crevice Corrosion}

Crevice corrosion can lead to failure of a component by wall penetration as well as failure due to hydrogen-induced cracking because of enhanced hydrogen absorption and transport into the metal. The obvious way to reduce hydrogen absorption via this route is to choose a more crevice corrosion resistant alloy. ${ }^{[80]}$ Improvements in resistance to crevice corrosion have been attributed to alloying elements, which reinforce passivity. Susceptibility to crevice corrosion is decreased through the alloying series $\mathrm{Ti} 2 \rightarrow \mathrm{Ti} 12 \rightarrow \mathrm{Ti} 16 .^{[80]}$ Decreased crevice corrosion rates by adding alloying elements such as Mo and Ni to Ti 12 and Pd to Ti 16 are noted by Shoesmith et al., ${ }^{[80]}$ and discussed in recent reviews of Ti crevice corrosion behavior. ${ }^{[81]}$ While some crevice corrosion occurs in Ti 2 , only minor crevice corrosion damage prior to repassivation occurs in $\mathrm{Ti} 12$ (alloyed with $\mathrm{Ni}$ and Mo which can segregate to grain boundaries and intermetallics). Adding Pd to $\mathrm{Ti}$ (to form $\mathrm{Ti} 16$ and $\mathrm{Ti}$ 7) does not lead to segregation and no crevice corrosion is observed.
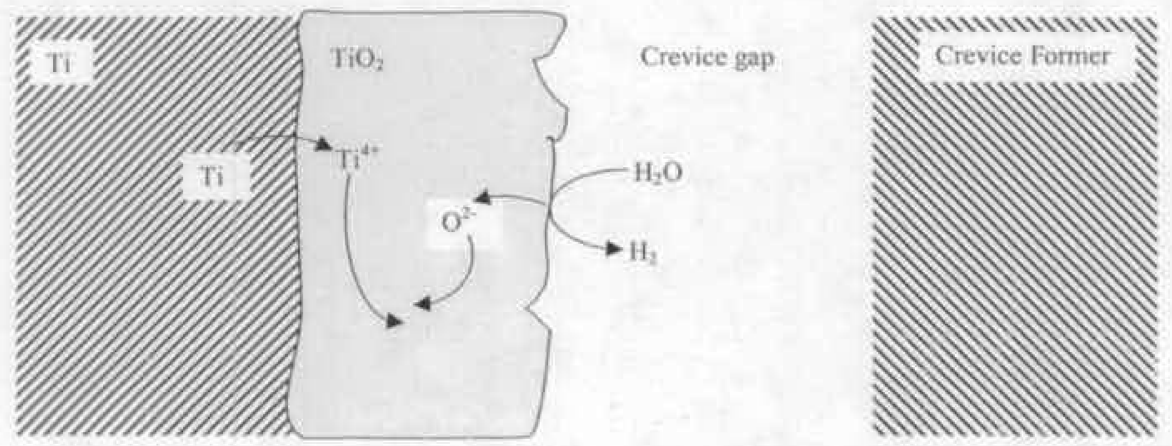

(A) Low Temperature Scenario
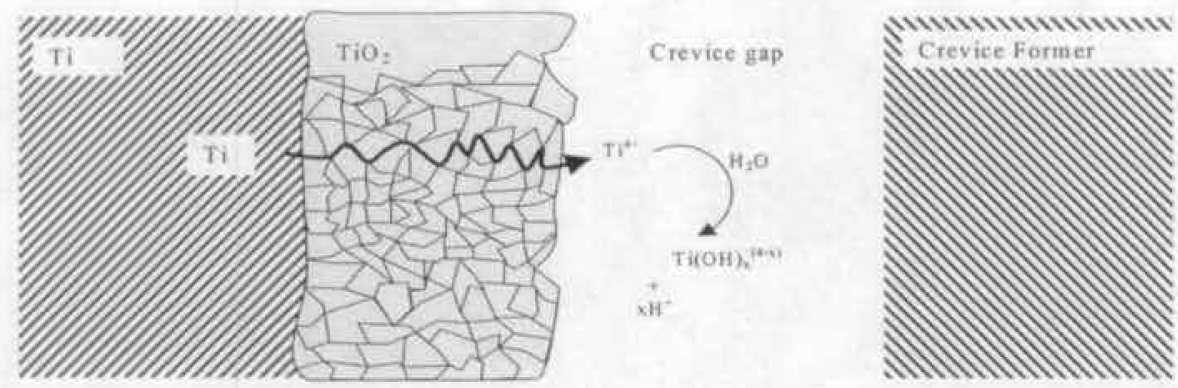

(B) Scenario at Temperatures $\geq 65^{\circ} \mathrm{C}$

Figure 7. Schematics illustrating the processes occurring within a creviced site at (A) low temperature $\left(<65^{\circ} \mathrm{C}\right)$, and $(\mathrm{B})$ temperatures greater than $65^{\circ} \mathrm{C} .^{[44]}$

Studies on $\mathrm{Ti} 16^{[53]}$ show that the resistance of the Pd-containing $\mathrm{Ti} 16$ to crevice corrosion is maintained at $100^{\circ} \mathrm{C}$ despite the etching of the creviced face, clear evidence for acidification within the crevice. This acidification can be attributed to the film breakdown/recrystallization process which occurs when the temperature is increased to $>65^{\circ} \mathrm{C}^{[53]}$ when crevice corrosion generally initiates on the more susceptible Ti-2. This is consistent with the industrial guideline for avoiding crevice corrosion, i.e., that the temperature must be $<70^{\circ} \mathrm{C}^{[19]}$ and with the results obtained by Shibata and Zhu. ${ }^{[82]}$ Breakdown/recrystallization leads to the introduction of grain boundaries, and possibly more open pathways, by which metal dissolution can occur. Under occluded crevice conditions, this leads to cation hydrolysis and the development of local acidity as illustrated schematically in Figure 7 . The 
need for film breakdown/recrystallization to produce localized acidity suggests that acidification requires temperatures higher than $\sim 65^{\circ} \mathrm{C}$ (see above). However, even at temperatures in the range $25^{\circ} \mathrm{C}$ to $35^{\circ} \mathrm{C}$, a drop in $\mathrm{pH}$ of a few units from neutral has been observed in laboratory-formed femoral taper crevices between Ti6Al4V and Cr-Co-Mo alloys. ${ }^{[83]}$ It can be seen from Table 1 that the composition of $\mathrm{Ti} 7$ is almost identical to that of $\mathrm{Ti} 16$, except the Pd content is higher in Ti $7(0.12$ $0.25 \%$ ) than in $\mathrm{Ti} 16(0.04-0.08 \%)$. Therefore, $\mathrm{Ti}$, like $\mathrm{Ti} 16$, is not expected to suffer any crevice corrosion damage either. This is confirmed in the Yucca Mountain Project's test results at LTCTF.

The model developed for the Ti 7 drip shield assumes that localized attack occurs only if the open circuit corrosion potential, $\mathrm{E}_{\text {corr }}$, exceeds the threshold potential for breakdown of the passive film, $E_{\text {critical. }}{ }^{[79]}$ This is a universally accepted criterion for processes such as pitting. Experimental measurements of $E_{\text {corr }}$ and $E_{\text {critical }}$ were obtained in various test environments expected in the repository. ${ }^{[79]}$ These test environments included simulated dilute water (SDW), simulated concentrated water (SCW), and simulated acidic water (SAW) at 30,60 , and $90^{\circ} \mathrm{C}$, as well as simulated saturated water (SSW) at 100 and $120^{\circ} \mathrm{C}$. SCW is about one thousand times more concentrated than $\mathrm{J}-13$ well water (a well located in the Yucca Mountain area) ${ }^{[84]}$ and is slightly alkaline (pH 8). SAW is about one thousand times more concentrated than $\mathrm{J}-13$ well water and is acidic $(\mathrm{pH} 2.7)$. The experimental measurements show that the threshold $\mathrm{E}_{\text {critical }}$ is consistently greater than $\mathrm{E}_{\text {corr }}$. The difference, $\mathrm{E}_{\text {critical }}$ $E_{\text {corr, }}$, falls in the range from $995 \mathrm{mV}$ to $1652 \mathrm{mV}$ (i.e., localized corrosion will not initiate) for the various test environments of SDW, SCW, SAW, and SSW at temperatures from $20-150^{\circ} \mathrm{C}$. It is therefore concluded that localized corrosion (pitting or crevice corrosion) will not contribute to the amount of hydrogen absorbed under repository exposure conditions.

\section{Hydrogen Absorption due to Galvanic Coupling of Ti Alloys to Other Metals}

The coupling of $\mathrm{Ti}$ to less active materials such as $\mathrm{Al}$ bronzes ${ }^{[85]}$ and $\mathrm{Cu}-\mathrm{Ni}$ alloys ${ }^{[86]}$ can also lead to the enhanced corrosion of the coupled material. Although no conclusive evidence is available, it seems unlikely that these couples can achieve galvanic corrosion potentials sufficiently cathodic to induce significant hydrogen absorption by titanium. The possibility of galvanic corrosion decreases markedly when the coupled material is passive, ${ }^{[86]}$ since the corrosion potentials for such materials are generally very close. This is the case for the materials of interest in waste package and drip shield applications as shown in Figure 8. The closeness of the galvanic potentials makes it difficult to decide which material in the couple will act as the cathode and which as the anode, but negligible galvanic interaction should occur as long as passivity is maintained. According to Schutz, ${ }^{[72]} \mathrm{Ti}$ should generally be the cathode in galvanic couples, but Reclaru and Meyer ${ }^{[68]}$ have shown Ti to be the anode when in contact with a series of dental alloys, although the galvanic currents were extremely low. Also, Wang et al. ${ }^{[65]}$ reported that $\mathrm{Ti} 2$ could be the anode or cathode when coupled to various materials in hot $\left(50^{\circ} \mathrm{C}\right.$ to $\left.90^{\circ} \mathrm{C}\right) 6 \% \mathrm{NaCl}$. Brass and alloy 600 were found to anodically polarize $\mathrm{Ti}$, while 316 stainless steel and Monel could polarize $\mathrm{Ti}$ either anodically or cathodically depending on temperature and $\mathrm{pH}$. However, the reliability of these last results is uncertain since it is not clear whether pretreatment of the specimens used in the experiments caused surface hydriding or not, or whether similarly polarized couples would be obtained for alternative geometries and coupled surface areas. 


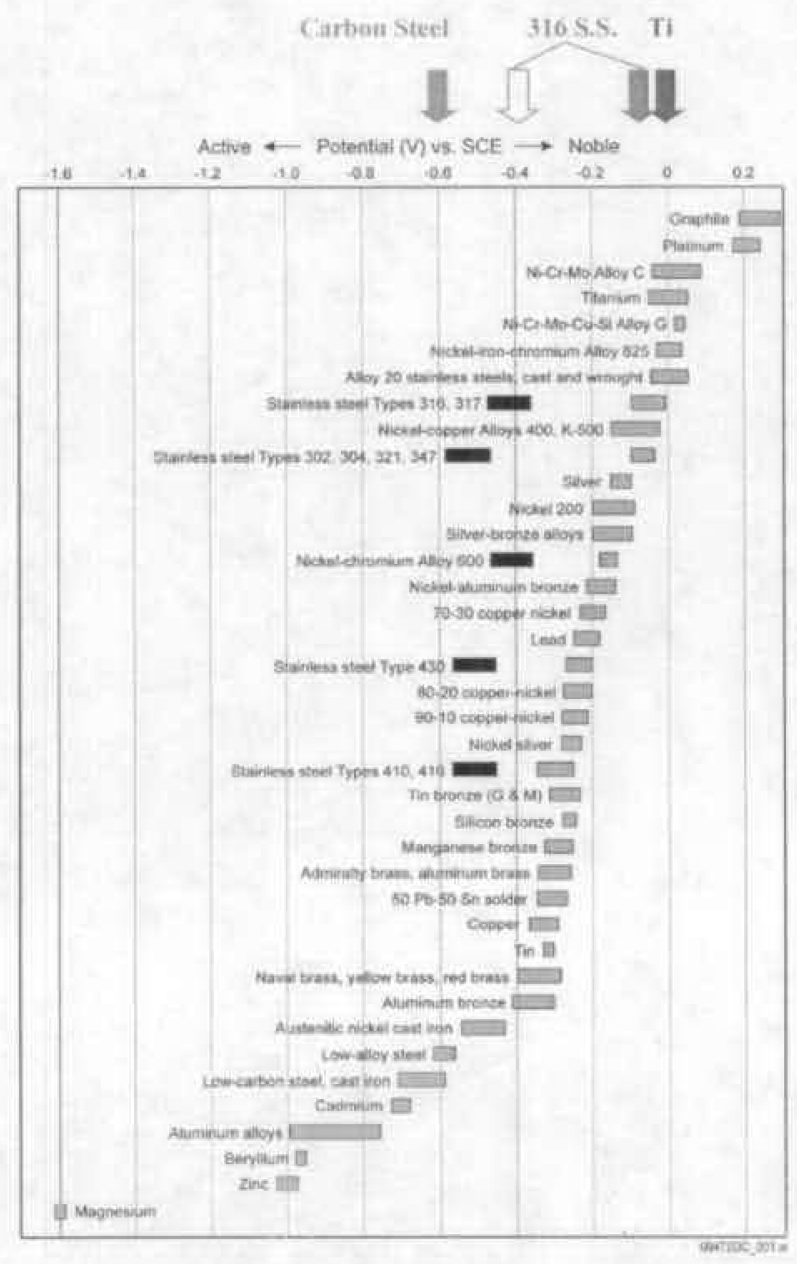

Figure 8. Galvanic series of metals in ambient seawater: Open arrow indicating active behavior of stainless steel Type $316^{[B 7]}$

The efficiency of Fe-Ti galvanic couples to cause hydrogen induced cracking of the titanium drip shield will nevertheless be limited for a number of additional reasons:

(1) The contact area is likely to be small and the anode to cathode area ratio (area of steel to titanium) low. Since relatively low volumes of groundwater are likely to contact both metals simultaneously, anode to cathode area ratios close to one are likely. If a couple with a small anode to cathode area ratio were established (i.e., a small piece of steel in contact with a large area of drip shield), then the couple would be rapidly exhausted as the steel was consumed. Under these conditions, the amount of hydrogen absorbed would be limited. Depending on how fast hydrogen diffuses into the surrounding $\mathrm{Ti}$, the hydrogen concentrations could be very low.

(2) While temperatures are high $\left(>80^{\circ} \mathrm{C}\right)$, the intermittent nature of seepage water contact will lead to only limited periods of the aqueous conditions required to sustain an active galvanic couple, thereby limiting hydrogen absorption while temperatures are high enough to drive hydrogen transport into the metal. For temperatures below $80^{\circ} \mathrm{C}$, even galvanic polarization below the potential threshold of -0.6

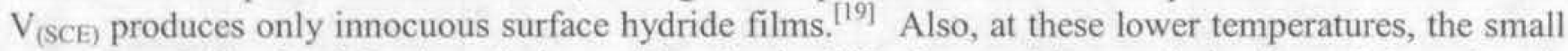
amounts of dissolved $\mathrm{O}_{2}$ in solution will make it difficult to achieve polarization of the galvanic potential to less than $-0.6 \mathrm{~V}_{(\mathrm{SCE}) \text {. Additionally, the intermittent wetting and drying cycles anticipated }}$ on the drip shield will lead to the formation of calcareous and other mineral deposits. Experimental 
evidence exists to show that galvanic currents ${ }^{[88]}$ and the rate of hydrogen absorption ${ }^{[74]}$ will decrease with time as deposits accumulate.

(3) Conditions in the repository will be oxidizing, making it less likely that the couple will sustain water reduction, and hence hydrogen absorption. However, in concentrated saline solutions at high temperatures, the amount of dissolved $\mathrm{O}_{2}$ should be too low to displace water reduction as the primary cathodic reaction. Also, the ferrous ion product of steel dissolution will be homogeneously oxidized to ferric species by dissolved $\mathrm{O}_{2}$. If conditions remain neutral, this should lead to the formation of insoluble $\mathrm{Fe}^{3+}$ oxides/hydroxides, so that little influence would be exerted on the galvanic couple. However, any tendency for acidification or the development of alkaline conditions will increase the ferric ion solubility. Under evaporative conditions, dissolved ferric ion concentrations could be high and lead to the establishment of a galvanic potential sufficiently positive to avoid hydrogen absorption. It is well documented that only parts per million concentrations of multivalent transition metal cations such as $\mathrm{Fe}^{3+}$ are required to polarize titanium to passive conditions ${ }^{[19,60,75]}$ and ferric oxide deposits are passivating to $\mathrm{Ti}^{[60,75]}$

(4) In the repository environment, both the Ti drip shield and steel component surfaces will experience a considerable dry period at high temperature $\left(\geq 85^{\circ} \mathrm{C}\right)$. This will leave both $\mathrm{Ti}$ and steel passivated (especially $\mathrm{Ti}$ ). While passivity on the steel may be subsequently disrupted, loss of passivity of the $\mathrm{Ti}$ drip shield is not so readily achieved. Experimental evidence exists to show that air oxidation prevents hydrogen absorption by $\mathrm{Ti}$ even in aggressive $(0.5 \%$ to $6 \% \mathrm{HCl})$ solutions at elevated temperatures $\left(70^{\circ} \mathrm{C}\right.$ to $\left.250^{\circ} \mathrm{C}\right) .{ }^{[89]}$

(5) Titanium has a large tolerance for hydrogen, and substantial concentrations must be achieved before any degradation in fracture toughness is observed. This concentration level has been measured to be in the range of 400 to $1,000 \mu \mathrm{g} / \mathrm{g}$ for Ti 2 and Ti 12 (see next section). Recent measurements suggest that the tolerance for hydrogen of the $\mathrm{Ti} 16$ (a titanium alloy very similar to $\mathrm{Ti} 7 \mathrm{in}$ chemical composition) may be in the 1,000 to $2,000 \mu \mathrm{g} / \mathrm{g}$ range. ${ }^{[54]}$

Given the high critical hydrogen concentration of $\mathrm{Ti}$ alloys, the large volume of available titanium in the drip shield into which absorbed hydrogen can diffuse, and the other reasons stated above, hydrogen embrittlement of the Ti drip shield is unlikely.

\section{CRITICAL HYDROGEN CONCENTRATION FOR HIC}

\section{Critical Hydrogen Concentration $\left(H_{C}\right)$ for HIC}

Using the slow strain rate technique on precracked compact tension specimens pre-charged with a known amount of hydrogen, Clarke et al. ${ }^{[90,91]}$ showed that the fracture toughness of Ti 2 and Ti 12 is not significantly affected until the hydrogen content exceeds a critical value, $\mathrm{H}_{\mathrm{C}}$. An example of the data obtained, expressed as a plot of stress intensity factor as a function of hydrogen concentration, is shown in Figure $9(\mathrm{a})$. 


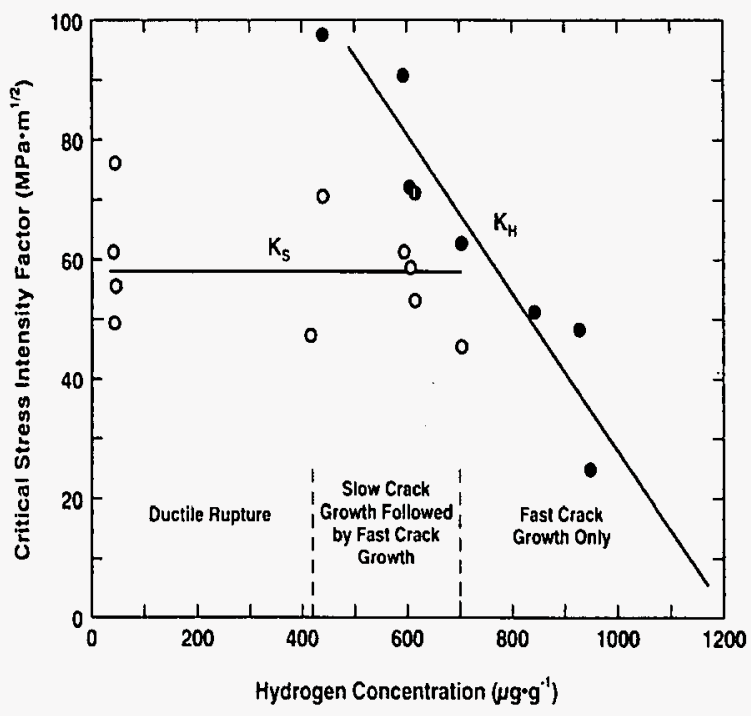

(a)

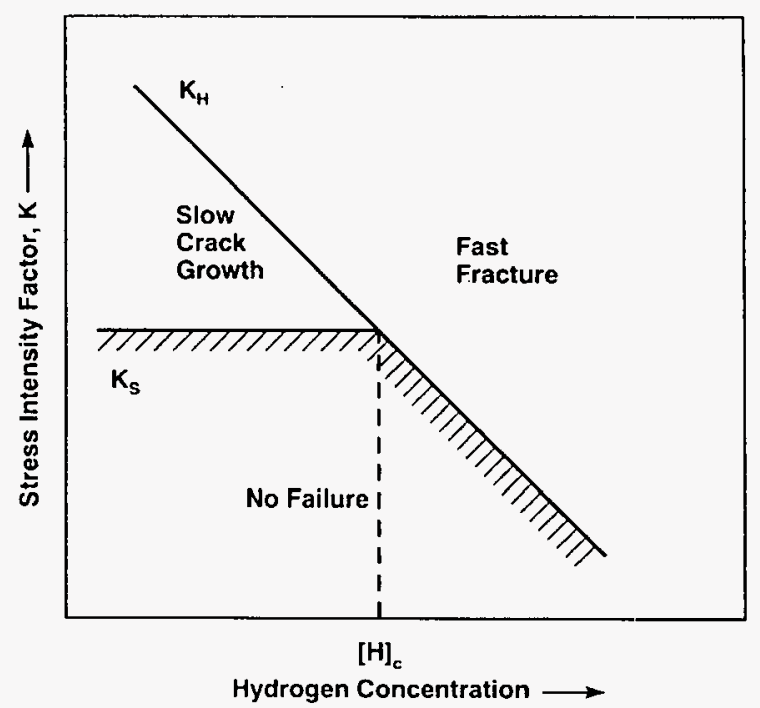

(b)

Figure 9. Variation of the critical stress intensity factor with hydrogen content for $\mathrm{Ti} 2$ (transverse-longitudinal [T-L] orientation): o - slow crack growth $\left(\mathrm{K}_{\mathrm{s}}\right)$; - - fast fracture $\left(K_{H}\right)(a)^{[90]}$ and schematic showing the combinations of stress intensity factor and hydrogen concentration leading either to fast crack growth (brittle failures, $\mathrm{K}_{\mathrm{H}}$ ), slow. crack growth $\left(\mathrm{K}_{\mathrm{s}}\right)$ due to either sustained load cracking or ductile rupture, or to no failure (b). ${ }^{[92]}$

$\mathrm{H}_{\mathrm{C}}$ is the hydrogen concentration above which slow crack growth is not observed, and only fast crack growth occurs. This does not necessarily mean that failure by fast crack growth is inevitable at this hydrogen content, but that the possibility of fast failure increases once this critical value is surpassed. Consequently, $\mathrm{H}_{\mathrm{C}}$ can be viewed as a property that defines a material's susceptibility to failure by HIC. $\mathrm{H}_{\mathrm{C}}$ is known to depend on the strength of the material. Materials with lower strength have a greater tolerance for hydrogen than materials with higher strength. ${ }^{[91]}$

A schematic form of Figure 9(a) is shown in Figure 9(b), ${ }^{[92]}$ illustrating how such experiments can be used to identify the $\mathrm{H}_{C}$ above which the fracture toughness is affected.

\section{$H_{C}$ of Ti 2 and $T i 12$}

Sorensen and coworkers ${ }^{[93]}$ showed that Ti 12 requires a hydrogen content of $>500 \mu \mathrm{g} / \mathrm{g}$ before any measurable loss of ductility occurs, based on the procedure described in the last section. $\mathrm{H}_{\mathrm{C}}$ is sensitive to the microstructure and texture of the material with respect to the orientation of the crack and the applied stress. Preferential pathways for cracking are formed along $\beta$-phase stringers introduced through the manufacturing process. An $\mathrm{H}_{\mathrm{C}}$ of $500 \mu \mathrm{g} / \mathrm{g}$ has been measured in $\mathrm{Ti} 12$ containing cracks propagating in the directions defined by these $\beta$-phase stringers. Crack propagation perpendicular to the $\beta$-phase stringers is not observed up to $2,000 \mu \mathrm{g} / \mathrm{g}$. Heat treatment to remove this laminar structure by randomly reorienting the residual $\beta$-phase can decrease $\mathrm{H}_{\mathrm{C}}$ to $\sim 400 \mu \mathrm{g} / \mathrm{g}$.

Even for manufactured plate materials that do not contain large amounts of $\beta$-phase, e.g., Ti 2 , the laminar structure introduced by rolling appears to dominate the cracking behavior. As a consequence, depending on crack orientation, $\mathrm{H}_{\mathrm{C}}$ varies between $\sim 400$ and $1,000 \mu \mathrm{g} / \mathrm{g}$. Since Ti 2 does not contain as much $\beta$-phase as $\mathrm{Ti} 12$, heat treatment does not exert a significant influence on $\mathrm{H}_{\mathrm{C}}$ 
for Ti 2. Welding produces a larger change in the microstructure than does heat treatment. The high weld temperature results in significant microstructural changes and a small decrease in strength. The heat-affected zone does not significantly influence the cracking behavior because, for both Ti 2 and Ti $12, \mathrm{H}_{\mathrm{C}}$ is only slightly decreased (but is still $>500 \mu \mathrm{g} / \mathrm{g}$ ) near the weld metal as compared to the base metal.

It should be noted that these values of $\mathrm{H}_{\mathrm{C}}$ were measured at room temperature $\left(\sim 22^{\circ} \mathrm{C}\right.$ to $\left.25^{\circ} \mathrm{C}\right)$. Clarke et al. ${ }^{\left[{ }^{00}\right]}$ have shown that $\mathrm{H}_{\mathrm{C}}$ for both Ti 2 and Ti 12 rises markedly with temperature, achieving a value of $\sim 1,000 \mu \mathrm{g} / \mathrm{g}$ in the temperature range $92^{\circ} \mathrm{C}$ to $100^{\circ} \mathrm{C}$. For $\mathrm{Ti} 2$; while the maximum critical stress intensity factor decreased slightly (from $50 \mathrm{MPa} \cdot \mathrm{m}^{1 / 2}$ to $40 \mathrm{MPa} \cdot \mathrm{m}^{1 / 2}$ ) at $95^{\circ} \mathrm{C}$, only slow crack growth is observed up to hydrogen concentrations of $\sim 2,000 \mu \mathrm{g} / \mathrm{g}$, clearly indicating a major increase in resistance to brittle crack growth as temperature increases. A similar increase in resistance to brittle fracture is observed for $\mathrm{Ti} 12$ at $95^{\circ} \mathrm{C}^{[90]}$ with the maximum stress intensity factor decreasing from $\sim 60 \mathrm{MPa} \cdot \mathrm{m}^{1 / 2}$ to $\sim 45 \mathrm{MP} \cdot \mathrm{am}^{1 / 2}$, while $\mathrm{H}_{\mathrm{C}}$ increased to $\sim 1,000 \mu \mathrm{g} / \mathrm{g}$. According to Clarke et al., increased creep deformation at higher temperatures is a major factor in preventing the development of a sufficiently high stress concentration to initiate fast fracture. ${ }^{[90]}$

\section{$H_{C}$ of $T i 7$ and $T i 16$}

Pd additions might affect the resistance of titanium alloys to HIC through-changes in mechanical properties. Kitayama et al. noted that the strength of Pd-containing alloys is affected by the oxygen content. ${ }^{[94]}$ Comparison of Ti 16 with Ti 17 , and Ti 7 with Ti 11 (Table 1 and Table 2) shows these alloy couples differ in strength due only to differences in oxygen content. Reducing oxygen content from $0.30 \mathrm{wt} \%$ for $\mathrm{Ti} 7$ and $\mathrm{Ti} 16$ to $0.18 \mathrm{wt} \%$ for $\mathrm{Ti} 11$ and $\mathrm{Ti} 17$ results in a reduction in

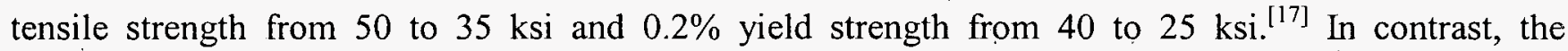
difference in $\mathrm{Pd}$ content between $\mathrm{Ti} 16$ and $\mathrm{Ti} 7$ does not lead to any difference in mechanical properties as also noted by. Schutz and Xiao. ${ }^{[50]}$

$\mathrm{H}_{\mathrm{C}}$ is a function of the stress intensity factor ${ }^{[92]}$ and, therefore, is determined by both the hydrogen solubility and the response to material stress. Ti 7 and 16 are $\alpha$-alloys containing minimal amounts of $\beta$-phase. It is reasonable, therefore, to expect that both alloys will exhibit similar responses to applied stresses in acidic environments. The role of palladium in improving resistance to HIC has been clearly demonstrated in the work of Gordon ${ }^{[95]}$ who compared the reduction in area (RA) of Ti 12 and $\mathrm{Ti} 7$ under cathodic polarization at $-1.2 \mathrm{~V}_{(\mathrm{Ag} / \mathrm{AgCl})}$. Ti 12 contains $0.3 \mathrm{wt} \%$ of $\mathrm{Mo}$ and $0.8 \mathrm{wt} \%$ of $\mathrm{Ni}$ without palladium in the $\alpha$-matrix, but with minor amounts of $\beta$-phase near grain boundaries. The results showed that while $\mathrm{Ti} 12$ had a ductility loss from about $40 \%$ to below $20 \%$, Ti 7 showed no significant change in RA. Greene et al. [96] concluded, based on calculations of hydrogen absorption/recombination, solubility and the free energy of hydride formation in $\mathrm{Ti}$ and $\mathrm{Pd}$, the $\mathrm{Ti}-\mathrm{Pd}$ alloys should exhibit a higher $\mathrm{H}_{\mathrm{C}}$ than titanium alloys without $\mathrm{Pd}$. Ikeda et al. ${ }^{[97]}$ studied the HIC behavior of $\mathrm{Ti} 16$ and compared the results with those obtained earlier for $\mathrm{Ti} 2$ and $\mathrm{Ti} 12 .{ }^{[80]}$ The authors concluded that the much higher $\mathrm{H}_{\mathrm{C}}$ for $\mathrm{Ti} 16$ compared to values for non-Pd bearing titanium alloys ( $\mathrm{Ti} 2$ and $\mathrm{Ti} 12$ ) is due predominantly to the prevention of hydride formation in the matrix by the higher solubility of hydrogen in $\mathrm{Pd}$-containing intermetallic particles. The authors further claimed that the intermetallic particles do not act as catalytic hydrogen absorption windows, but may function as proton discharge sites favoring hydrogen gas production.

The above evidence suggests that the $\mathrm{H}_{\mathrm{C}}$ of $\mathrm{Ti} 7$ should be at least as high as, if not higher than, that of Ti 16. Ikeda and Quinn ${ }^{[54,55]}$ reported that an $H_{C}$ value for Ti 16 between 1,000 and 2,000 $\mu \mathrm{g} / \mathrm{g}$, and it can be conservatively assumed that the $\mathrm{H}_{\mathrm{C}}$ for $\mathrm{Ti} 7$ is at least $1,000 \mu \mathrm{g} / \mathrm{g}$. ${ }^{[98]}$ This choice 
is conservative for a number of reasons; (1) the value has been taken to be identical to that for Ti 16 wheras a higher value would be anticipated due to the higher $\mathrm{Pd}$ content; and (2) $\mathrm{H}_{\mathrm{C}}$ was measured at room temperature, but the drip shield temperature will be substantially higher and, as discussed above, $\mathrm{H}_{\mathrm{C}}$ increases significantly with temperature.

\section{$H_{C}$ of $T i 5, T i 24$ and $T i 29$}

An experimentally obtained critical hydrogen concentration for Ti 24 is not presently available. However, the corrosion behavior of $\mathrm{Ti} 24$ and an approximate $\mathrm{H}_{\mathrm{C}}$ value for this alloy can be estimated from that of Ti 5 based on a similar comparison to that used to estimate the behavior of Ti 7 from that measured for $\mathrm{Ti} 2$ and 16.

Tables 1 and 2 show that addition of palladium to titanium alloys does not influence their mechanical properties whereas the $\mathrm{Al}$ and $\mathrm{V}$ contents do. Three groups of titanium alloys listed in Table 1 and Table 2 (Ti 2, 7, and 16; Ti 5 and 24, Ti 9 and 18) have the same tensile strength, yield strength, and other mechanical properties within the group, although other alloying elements alter their mechanical properties despite the differences in $\mathrm{Pd}$ content.

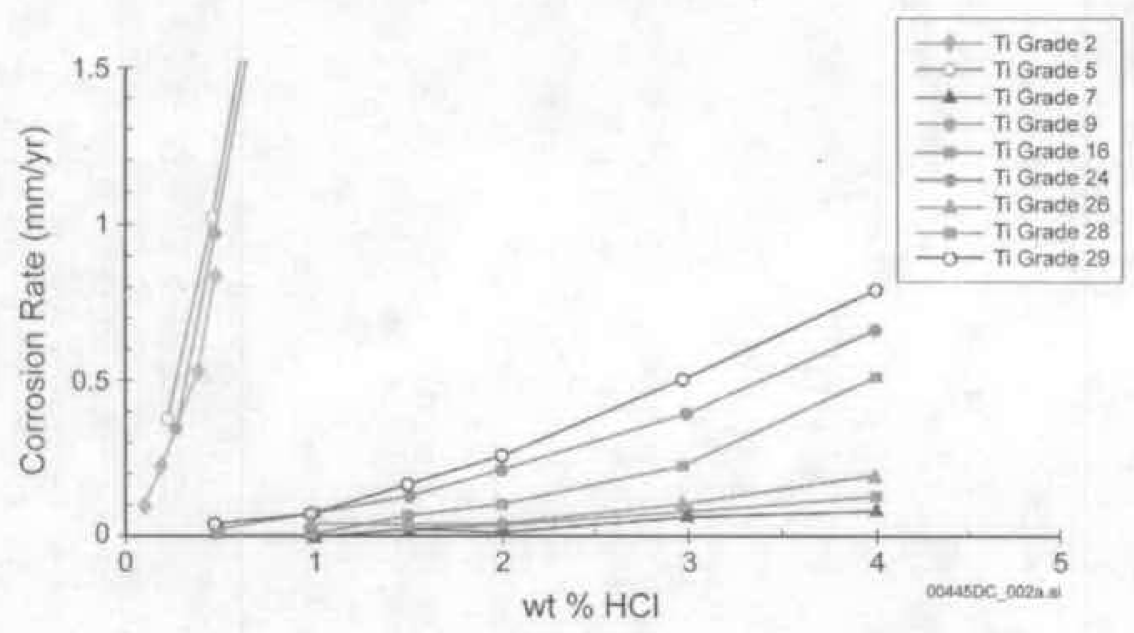

Figure 10. Corrosion rates of $\mathrm{Ti} 2,5,7,17,24$ and 29 in Boiling $\mathrm{HCl}$ (Regenerated using new data from Ref [20])

As shown in Figure 10, testing of Ti 5, its Pd-modified version (Ti 24), and its Ru-modified version ( $\mathrm{Ti} 29$ ) in boiling $\mathrm{HCl}$ showed that the addition of $\mathrm{Pd}$ or $\mathrm{Ru}$ to $\mathrm{Ti} 5$ improves the alloy's corrosion resistance in an analogous manner to that observed when Pd is added to the Ti 2 alloy to produce Ti 16 and $\mathrm{Ti} 7 .^{[20,50,99]}$ The mechanism by which $\mathrm{Pd}$ improves the corrosion resistance of Ti 24 compared to $\mathrm{Ti} 5$ is expected to be similar to that for $\mathrm{Ti} 7$ and 16 as to when compared to Ti 2, i.e., the accumulation of Pd in the corroding surface ennobles the corrosion potential of the alloys and the addition of $\mathrm{Pd}$ increases the hydrogen solubility in the alloy.

$\mathrm{H}_{\mathrm{C}}$ has been established for Ti 5 using an identical experimental technique to that employed to determine the $\mathrm{H}_{\mathrm{C}}$ values for $\mathrm{Ti} 2,12$, and $16 .^{[100]}$ Using the slow strain rate technique on pre-cracked compact tension specimens pre-charged with known amounts of hydrogen, Hardie and Ouyang showed that the fracture toughness of Ti 5 was not significantly altered until the hydrogen level in the alloy exceeded $200 \mu \mathrm{g} / \mathrm{g} .{ }^{[00]}$ For smooth tensile specimens, the authors showed that the reduction in area 
and elongation of Ti 5 did not decrease until the hydrogen concentration reached about 1,500 ppm. ${ }^{[100]}$ Based on the above discussion, a modest improvement to $600 \mu \mathrm{g} / \mathrm{g}$, if not higher, is not an unreasonable estimate of the $\mathrm{H}_{\mathrm{C}}$ value for $\mathrm{Ti} 24$. Considering the higher strength of $\mathrm{Ti} 24$ compared to Ti 16 and Ti 7, it can be estimated conservatively that the $\mathrm{H}_{\mathrm{C}}$ of Ti 24 should be in the range of 400 $600 \mu \mathrm{g} / \mathrm{g}$, if not higher. ${ }^{[98]}$ This estimated value of $\mathrm{H}_{\mathrm{C}}$ is conservative. For instance, Kitayama et al. ${ }^{[99]}$ evaluated the effect of Pd addition to Ti-6Al-4V (Ti 5) and $\mathrm{Ti}-3 \mathrm{Al}-2.5 \mathrm{~V}$ (Ti 9) on their hydrogen induced cracking behavior. By cathodically charging hydrogen into Pd-containing Ti-6Al-4V (an equivalent to $\mathrm{Ti} 24$ ) to approximately 1,000 and $1,100 \mathrm{ppm}$, the 0.2 percent proof stress was found to be 175 and $145 \mathrm{ksi}$, respectively, ${ }^{[99]}$ suggesting that no degradation in mechanical properties occurred for this level of hydrogen content.

As mentioned earlier in the text and shown in Table 2, Ti 29 has a bit lower strength than its palladium containing analog $\mathrm{Ti} 24$. The lower strength is expected to provide $\mathrm{Ti} 29$ with an added advantage over Ti 24 in terms of resistance to HIC. According to previous workers, ${ }^{[92]}$ materials with lower strength have greater tolerance for hydrogen than those with higher strengths. Consequently, the $\mathrm{H}_{\mathrm{C}}$ of $\mathrm{Ti} 29$ is expected to be at least equal to that for Ti 24 , i.e., in the range of $400-600 \mu \mathrm{g} / \mathrm{g}$, if not greater.

\section{MODELING HIC OF TITANIUM ALLOYS}

The HIC modeling has been performed in this review following a Canadian precedence. ${ }^{[80]} \mathrm{A}$ previously developed mathematical model (mentioned below) has been used to estimate the hydrogen content in titanium alloys in 10,000 years under repository conditions. Then, the hydrogen concentration, thus obtained, has been compared with the threshold concentration required for HIC of titanium alloys to assess whether the drip shield will fail via HIC within 10,000 years of emplacement or not. ${ }^{[98]}$. Failure of the drip shield via fast fracture is assumed to occur instantly once the hydrogen concentration in the drip shield reaches the critical hydrogen concentration required for hydrogen embrittlement of the drip shield materials. ${ }^{[98]}$

Initially, the underlying waste packages will be relatively hot, and drip shield surfaces will be dry due to the heat generated from radioactive decay. The temperature will eventually drop to levels where both humid air and aqueous phase passive corrosion are possible. Both types of corrosion will produce hydrogen, which could be absorbed into the metal. ${ }^{[80]}$ In a drip shield design without backfill, hydrogen generation may be caused by galvanic coupling between the titanium drip shield and ground support elements (such as rock bolts, wire mesh, and steel liners used in the drift), which may fall onto the drip shield surface. Failure occurs if (1) the wall penetration by corrosion exceeds the corrosion allowance, or (2) the amount of hydrogen absorbed exceeds the critical hydrogen concentration, $\mathrm{H}_{\mathrm{C}}$, for failure due to HIC.

\section{Efficiency of Hydrogen Absorption}

Not all of the hydrogen produced in corrosion processes on $\mathrm{Ti}$ alloys is absorbed. The fractional efficiency for hydrogen absorption into titanium used in drip shield corrosion modeling, $f_{h}$, is in the range of 0.005 to 0.015 , as reported by Okada. ${ }^{[28]}$ Okada measured the fractional efficiency of hydrogen absorption for Ti 2 at a constant applied current of $0.5 \mathrm{~mA} / \mathrm{cm}^{2}$ in acidic sodium sulfate solutions at $\mathrm{pH}=4\left(25^{\circ} \mathrm{C}\right)$. The electrode potential achieved during these experiments was -1.14 $\mathrm{V}_{\text {(SCE) }}$, about $500 \mathrm{mV}$ more negative than the threshold value of $-0.6 \mathrm{~V}_{\text {(SCE) }}$ for hydrogen absorption and 250 to $400 \mathrm{mV}$ more negative than would be achieved through galvanic coupling of $\mathrm{Ti}$ to carbon steel. ${ }^{[88]}$ At these potentials, redox transformations in the oxide render it permeable to hydrogen. ${ }^{[80]}$ 
Similar measurements on Pt and Ni-coated Ti 2 specimens gave a value of $f_{h}$ only marginally higher under these conditions, a clear indication that the Pd-content of $\mathrm{Ti} 7$ would not be expected to increase this value when passive conditions prevail. The applied current density used was $0.5 \mathrm{~mA} / \mathrm{cm}^{2}$ compared to a value of $2.85 \mathrm{nA} / \mathrm{cm}^{2}$ calculated as the current that would flow at a general corrosion rate of $50 \mathrm{~nm} / \mathrm{yr}$ (the $70^{\text {th }}$ percentile value of general corrosion rates measured for 1-year exposed Ti 16 specimens in the LTCTF. ${ }^{[79]}$ ) Such aggressive electrochemically polarized conditions are unachievable in the repository.

A number of studies have been published which clearly show that the rate of hydrogen absorption decreases parabolically with time. ${ }^{[29,30,31,49,73,101]}$ Tomari et al. ${ }^{[29]}$ and Phillips et al. ${ }^{[73]}$ showed that the parabolic relationship for hydrogen absorption possessed a $t^{1 / 2}$ time-dependence i.e., the hydrogen absorption process is controlled by the transport of hydrogen from the surface layer into the bulk of the alloy. The presence of the surface hydride, or the storage of hydrogen in a concentrated surface layer, was confirmed optically, ${ }^{[49,73]}$ by glow discharge spectroscopy ${ }^{[102]}$ and by Secondary Ion Mass Spectrometry (SIMS) depth profiling. ${ }^{[29]}$ Glow discharge spectroscopy was also used to show the change in distribution of hydrogen in the alloy as a consequence of transport over time. Tomari et al. ${ }^{[29]}$ reported an $f_{h}$ value of 0.00014 obtained by experiments conducted for 1,440 hours under electrochemically polarized conditions. Thus, using a constant upper boundary $f_{h}$ value in modeling hydrogen absorbed in titanium alloys is sufficiently conservative. ${ }^{[98]}$

\section{Hydrogen Content During General Passive Corrosion}

Based on a constant film growth rate and, hence, corrosion rate, Shoesmith et al. ${ }^{[80]}$ derived that the concentration of hydrogen in titanium can be calculated as a function of time of emplacement $(t$ in years) from the expression:

$$
H_{A}=4\left(\rho_{T i} / 10^{3}\right) f_{h} R_{u c} t\left[M_{T i}\left(d_{o}-R_{u c} t\right)\right]^{-1}
$$

where $H_{A}$ is the hydrogen content $\left(\mathrm{g} / \mathrm{mm}^{3}\right), \rho_{\mathrm{Ti}}$, the density of $\mathrm{Ti}\left(4.50 \mathrm{~g} / \mathrm{cm}^{3}\right),{ }^{[103]} \mathrm{f}_{\mathrm{h}}$, the fractional efficiency for hydrogen absorption, $R_{u c}$, the rate of general passive corrosion $(\mathrm{mm} / \mathrm{yr}), \mathrm{t}$, the time of emplacement (years), $M_{\mathrm{Ti}}$, the atomic mass of $\mathrm{Ti}(47.9 \mathrm{~g} / \mathrm{mol}),{ }^{[103]}$ and $\mathrm{d}_{\mathrm{o}}$ is the half thickness of the metal.

The general corrosion rates for $\mathrm{Ti} 16$ and $\mathrm{Ti} 7$ in repository relevant environments have been measured in 1, 2.5 and 5 years immersion test in repository relevant environments ${ }^{[79]}$ The 1 -year, 2.5 year and 5-year corrosion rates for $\mathrm{Ti} 7$ and $\mathrm{Ti} 16$ are shown in Table 3. ${ }^{[79]}$ These rates were determined from weight loss measurements. The drip shield is assumed to corrode on both the upper and lower surfaces. For the lower surface, where only humid atmosphere corrosion will occur, rates measured on planar specimens were used. Where aqueous conditions due to seepage could also exist, the possibility of localized acidification under deposits is acknowledged and corrosion rates are calculated from a combination of measurements on planar and creviced specimens. The average of the maximum values in Table 3 are used in estimating the hydrogen content in the drip shield.

Table 3. Summary of One-, Two and a Half- and Five-Year Corrosion Data Comparison ${ }^{[79]}$

\begin{tabular}{|c|c|c|c|c|c|c|}
\hline & \multicolumn{2}{|c|}{$\begin{array}{c}\text { One -Year (nm/yr), } \\
\text { Ti 16 }\end{array}$} & $\begin{array}{c}\text { Two and a Half-Year (nm/yr), } \\
\text { Ti 7 }\end{array}$ & \multicolumn{2}{c|}{$\begin{array}{c}\text { Five-Year (nm/yr), } \\
\text { Ti 16 }\end{array}$} \\
\hline Specimen Type & Weight-Loss & Crevice & Weight-Loss & Crevice & Weight-Loss & Crevice \\
\hline Median & 0 & 0 & 6 & 3 & 5 & 10 \\
\hline Maximum & 113 & 319 & 50 & 38 & 58 & 77 \\
\hline
\end{tabular}


As discussed previously, the fractional efficiency for hydrogen absorption is in the range of 0.005 to 0.015 , as reported by Okada. ${ }^{[28]}$ This is a conservative value since Okada's measurements were conducted using applied currents and potentials which are not achievable under repository exposure conditions even under of galvanic coupling conditions.

Table 4. Hydrogen Contents in Ti 7 10,000 years after emplacement as calculated based on oneyear, two and one-half-year and five-year corrosion rate data ${ }^{[98]}$

\begin{tabular}{|c|c|c|c|}
\hline & $\begin{array}{c}\text { One-Year Data } \\
\text { Ti 16 }\end{array}$ & $\begin{array}{c}\text { Two and One-Half- } \\
\text { Year Data } \\
\text { Ti } 7\end{array}$ & $\begin{array}{c}\text { Five-Year Data } \\
\text { Ti 16 }\end{array}$ \\
\hline $\begin{array}{c}\text { Hydrogen Content } \\
(\mu \mathrm{g} / \mathrm{g})\end{array}$ & 507 & 78 & 124 \\
\hline
\end{tabular}

Using $\mathrm{f}_{\mathrm{h}}=0.015, \mathrm{~d}_{\mathrm{o}}=7.5 \mathrm{~mm}, \mathrm{t}=10,000$ years and the average values of the maximum corrosion rates in Table 3, Equation 1yields $\mathrm{H}_{\mathrm{A}}=507,78$, and $124 \mu \mathrm{g} / \mathrm{g}$, for the one-year (Ti 16) data, the two and one-half year ( $\mathrm{Ti}$ 7) data, and the five-year (Ti 16) data, respectively (Table 4). Under all circumstances, the calculated hydrogen content is well below the critical hydrogen concentration, $\mathrm{H}_{\mathrm{C}}$ $(1,000 \mu \mathrm{g} / \mathrm{g})$ for Ti 7 and Ti $16 .^{[98]}$

To date there is scant information in the literature on $\mathrm{H}_{\mathrm{C}}$ of $\mathrm{Ti} 24$, a $\alpha-\beta$ alloy, which is to be used as the structural support material for the Ti 7 drip shield. However, based on critical analysis of the limited information available in the scientific literature, $\mathrm{H}_{\mathrm{C}}$ of $\mathrm{Ti} 24$ has been estimated to be in the range of $400-600 \mu \mathrm{g} / \mathrm{g}$ (see above). Again, for want of experimental data on the general corrosion rate of Ti 24 in the repository relevant environment, a recent Yucca Mountain Project report ${ }^{[98,104]}$ has conservatively estimated $\mathrm{R}_{\mathrm{uc}}$ of $\mathrm{Ti} 24$ to be 5 times that observed for $\mathrm{Ti} 7$ in experiments conducted in a repository relevant environment. The rationale for this estimation is that the passive general corrosion rate of $\mathrm{Ti} 24$ in a reducing acid environment is 5 times that for Ti 7 (see Figure 10). Further, the handbook data ${ }^{\left[{ }^{[9]}\right.}$ shows the passive general corrosion rate of the palladiumless analog of $\mathrm{Ti} 24$ (i.e., $\mathrm{Ti}$ 5) in an oxidizing acid environment is 4 times that for $\mathrm{Ti}$.7. The later data is considered repository relevant because the environment in Yucca Mountain repository is oxic. In addition, due to lack of an experimental value for the fractional hydrogen absorption efficiency $\left(f_{h}\right)$ of Ti 24 , an adapted value of $f_{h}=0.015$ was used for the estimation of the total concentration of hydrogen in Ti 24 . Using Equation 1, an $\mathrm{H}_{\mathrm{A}}$ value of $372 \mu \mathrm{g} / \mathrm{g}$ was obtained for Ti 24 in 10,000 years. Obviously, this value is lower than the critical hydrogen concentration (e.g., $400-600 \mu \mathrm{g} / \mathrm{g}$ ) necessary for the occurrence of $\mathrm{HIC}$ of Ti-24. Consequently, the Ti24 structural support material, just like the Ti 7 plate material, also is not expected to fail via HIC (or hydrogen embrittlement) in 10,000 years.

It should be noted that $\mathrm{H}_{\mathrm{A}}$ value for Ti 29 in 10,000 years could not be assessed due to unavailability of the general corrosion rate data for this material in Yucca Mountain relevant environments. As a result, this review is inconclusive as to whether $\operatorname{Ti} 29$, a potential alternative structural support material for the drip shield, will actually resist hydrogen embrittlement for 10,000 years in the repository environment or not.

\section{CONCLUDING REMARKS}

Due to differences in hydrogen solubility between the hexagonal close-packed $\alpha$ phase and the body-centered cubic $\beta$ phase, strong effects of microstructure on HIC are observed in near- $\alpha$ and $\alpha-\beta$ Ti alloys. Addition of $0.12-0.25 \mathrm{wt} \%$ palladium to pure titanium improves its corrosion resistance without altering its microstructure (and, therefore, mechanical properties) of the material. Although alloying elements like Pd reportedly lowers the threshold potential for hydrogen uptake, experimental evidence for the enhancement of hydrogen absorption due to Pd is not conclusive. Other alloying 
elements can influence hydrogen absorption through the formation of intermetallics, which can serve as "hydrogen windows" and/or hydrogen storage sites and thereby enhance hydrogen embrittlement of $\beta$ and $\alpha-\beta$ alloys of titanium . However, if the titanium alloy is covered with a defect-free oxide film, then all these undesirable effects of alloying additions to titanium could be nullified. This is possible because a defect-free oxide film on titanium alloy is impervious to hydrogen. Therefore, environmental conditions, which are conducive to the formation of a defect-free oxide film on titanium alloys, are needed in the repository for a sufficiently long period of time so that the drip shield can develop a defect-free oxide coating around it before its contact with the seepage water occurs. Due to initial slow heating period of a few hundred years in relatively dry atmosphere, the drip shield is duly expected to develop a relatively defect-free oxide coating around it long before the seepage water can contact it. This expected situation is to be extremely helpful in resisting the HIC of the drip shield components in the Yucca Mountain repository.

Using the average value of the maximum passive general corrosion rates measured in 1-year (Ti 16), 2.5-year ( $\mathrm{Ti} 7$ ) and 5-year (Ti 16) immersion tests and a conservative fractional efficiency for hydrogen absorption, the hydrogen concentrations after 10,000 years of emplacement were estimated to be 510,78 and $124 \mu \mathrm{g} / \mathrm{g}$, respectively. These values are well below the estimated critical hydrogen concentration $\left(\mathrm{H}_{\mathrm{C}}\right)$. The effects of galvanic coupling between the Ti 7 drip shield material and a finite carbon steel segment were studied elsewhere ${ }^{[98,105]}$. Several relevant combinations of model parameters were used and none of these combinations resulted in hydrogen contents above the 1,000 $\mu \mathrm{g} / \mathrm{g}$ threshold value. Based on these results, it can be concluded that the hydrogen generated by passive general corrosion and galvanic coupling to carbon or stainless steels will not be sufficient for hydrogen-induced cracking to occur in $\mathrm{Ti} 7$ even after 10,000 years of emplacement. Since the estimated value of hydrogen concentration $\left(\mathrm{H}_{\mathrm{A}}\right)$ in $\mathrm{Ti} 24$ in 10,000 years (i.e., $372 \mu \mathrm{g} / \mathrm{g}$ ) is lower than the hydrogen concentration value critically required (i.e., $400-600 \mu \mathrm{g} / \mathrm{g}$ ) for the HIC of Ti-24, the structural support material should not fail by HIC in 10,000 years. . Thus, both Ti 7 plate and Ti 24 structural support components of the drip shield will be able to function concurrently for continued long life of the drip shield enabling it to perform its seepage water diversion function for more than 10,000 years in the Yucca Mountain repository.

\section{ACKNOWLEDGEMENTS}

This work was performed and funded under DOE contract DE-AC08-01RW12101 for the Civilian Radioactive Waste Management System (CRWMS) led by the prime contractor Bechtel SAIC Company, LLC.

\section{REFERENCES}

[1] Act 1987. Nuclear Waste Policy Amendments Act of 1987. Public Law No. 100-203, 101 Stat. 1330

[2] DOE (U.S. Department of Energy) 2002. Yucca Mountain Science and Engineering Report. DOE/RW-0539, Rev. 1.

[3] Farmer, J.; McCright, D.; Gdowski, G.; Wang, F.; Summers, T.; Bedrossian, P.; Horn, J.; Lian. Y.; Estill, J.; Lingenfelter, A.; and Halsey, W. 2000. "General and Localized Corrosion of Outer Barrier of High-Level Waste Container in Yucca Mountain," Proceeding of ASME/PVP Conference, American Society of Mechanical Engineers, Seattle, Washington, July 23-27, 2000.

[4] Andresen, P.L.; Emigh, P.W.; Young L.M.; and Gordon G.M. 2001. "Stress Corrosion Cracking of Anrealed and Cold Worked Titanium 7 and Alloy 22 in $110^{\circ} \mathrm{C}$ Concentrated Salt Environments," Corrosion 2001, Paper No. 01130, NACE International.

[5] Dunn, D.S.; Pan Y.M.; and Cragnolino, G.A. 2000. "Stress Corrosion Cracking, Passive, and Localized Corrosion of 
Alloy 22 High Level Radioactive Waste Containers." Corrosion 2000, Paper No. 00206, NACE International. Houston, Texas.

[6] Roy, A. and Flemming, D. 1999. "Galvanic Corrosion - Effect of Environmental and Experimental Variables," Corrosion 1999, Paper No. 465, NACE International.

[7] Roy, A. and Flemming, D. 1998. "Galvanic Corrosion Study of Container Materials Using Zero Resistance Ammeter." Corrosion 1998, Paper No. 156, NACE International.

[8] Lian, T.; Martin, S.; Jones, D.; Rivera, A.; and Horn, J. 1999. "Corrosion of Candidate Container Materials by Yucca Mountain Bacteria." Corrosion 1999, Paper No. 476, NACE International.

[9] Horn, J.; Martin, S.; Masterson, B.; and Lian, T. 1999. "Biochemical Contributions to Corrosion of Carbon Steel and Alloy 22 in a Continual Flow System." Corrosion 1999, Paper No. 162, NACE International.

[10] Horn, J.; Martin, S.; Rivera, A.; Bedrossian, P.; and Lian, T. 2000. "Potential Biogenic Corrosion of Alloy 22, A Candidate Nuclear Waste Rackaging Material, Under Simulated Repository Conditions," Corrosion 2000, Paper No. 00387, NACE International.

[11] Hua, F.; Sarver, J.; Jevec, J.; and Gordon, G. 2002. "General Corrosion Studies of Candidate Container Materials in Environments Relevant to Nuclear Waste Repository." Corrosion 2002, Paper No. 02530, NACE International.

[12] Hua, F. and Gordon, G. 2004. "Corrosion Behavior of Alloy 22 and Ti 7 in a Nuclear Waste Repository Environment." Corrosion. 60, (8), 764-777. Houston, Texas: NACE International.

[13] Hua, F. and Gordon, G. 2003. "On Apparent Bi-Linear Corrosion Rate Behavior of Ti 7 in Basic Saturated Water (BSW-12) Below and Above $80^{\circ} \mathrm{C} . "$ Corrosion 2003, Paper No. 03687, NACE International.

[14] Gdowski, G.E. 1997. Degradation Mode Survey Candidate Titanium - Base Alloys for Yucca Mountain Project Waste Package Materials. UCRL-ID-121191, Rev. 1.

[15] Paton, N.E. and Williams, J.C. 1974. "Effect of Hydrogen on Titanium and Its Alloys", in Hydrogen in Metals, Bernstein, I. M. and Tompson, A. W. eds., American Society for Metals, 409-431.

[16] Moody, N.R. and Costa, N.R. 1991. "A Review of Microstructure Effects on Hydrogen-Induced Sustained Load Cracking in Structural Alloys," in Microstructure/Property Relationships in Titanium Aluminides and Alloys, Kim, Y.-W and Boyer, R. R. (eds), Minerals, Metals \& Materials Soc (TMS), Warrendale, PA, USA. 587-604.

[17] ASTM B 265-02. 2002. Standard Specification for Titanium and Titanium Alloy Strip, Sheet, and Plate. Philadelphia, Pennsylvania: American Society for Testing and Materials.

[18] Shih, D.S.; Robertson, I. M; and Brinbaum, 1988. Acta Metallurgica, 36 (1), 111 (1988).

[19] Schutz, R.W. and Thomas, D.E. 1987. "Corrosion of Titanium and Titanium Alloys." In Corrosion, Volume 13, 669-

706 of $A$ SM Metals Handbook.

[20] Schutz, R.W. 1995. "Recent Titanium Alloy and Product Developments for Corrosive Industrial Service." Corrosion 95, Paper No. 244, 244/1-244/20.

[21] Schutz, R.W. 2003. "2003 F.N. Speller Award Lecture: Platinum Group Metal Additions to Titanium: A Highly Effective Strategy for Enhancing Corrosion Resistance." Corrosion, 59, (12), 1043-1057.' [Houston, Texas]: NACE International.

[22] Uhlig, H.H. 1948. The Corrosion Handbook. John Wiley and Sons, New York. 1144-1145.

[23] Greef, R.; Peat, R.; Peter, L.M.; Pletcher, D.; and Robinson, J. 1985. "Electrocatalysis." Chapter 7 of Instrumental Methods in Electrochemistry.

[24] Murai T.; Ishikawa, M.; and Miura, C. 1977. "The Absorption of Hydrogen into Titanium Under Cathodic Polarization." Corrosion Engineering, 26(4), 177-183.

[25] Shoesmith, D.W. and B.M. Ikeda. 1997. The Resistance of Titanium to Pitting, Microbially Induced Corrosion and Corrosion Under Unsaturated Conditions. Atomic Energy of Canada Limited Report, AECL-11709, COG-96-557-I.

[26] Beck, T.R. 1973. "Pitting of Titanium. I. Titanium Foil Experiments." J. Electrochem. Soc, 120,1317-1316.

[27] Beck, T.R. 1973. Pitting of Titanium. II. One-Dimensional Pit Experiments." J. Electrochem. Soc, 120, 1317-1324.

[28] Okada, T. 1983. "Factors Influencing the Cathodic Charging Efficiency of Hydrogen by Modified Titanium Electrodes." Electrochimica Acta, 28, (8), 1113-1120.

[29] Tomari, H.; Masugata, T.; Shimogori, K.; Nishimura, T.; Wada, R.; Honda, A.; and Taniguchi, N. 1999. "Hydrogen Absorption of Titanium for Nuclear Waste Container in Reducing Condition." Zairyo-to-Kankyo, 48, 807-814.

[30] Kim, Y.J. and Oriani, R.A. 1987. Brine Radiolysis and its Effect on the Corrosion of Grade-12 Titanium. Corrosion, 43, 92-97.

[31] Kim, Y.J. and Oriani, R.A. 1987. "Corrosion Properties of the Oxide Film Formed on Grade-12 Titanium in Brine Under Gamma Radiation." Corrosion, 43, 85-91.

[32] Covington, L.C. 1979. "The Influence of Surface Condition and Environment on the Hydriding of Titanium." Corrosion, 35 (8), 378-382.

[33] Shimogori, K.; Satoh, H.; and Kamikubo, F. 1985. "Investigation of Hydrogen Absorption-Embrittlement of Titanium Used in the Actual Equipment." Titanium, Science and Technology, Proceedings of the Fifth International Conference on 
Titanium, Congress-Center, Munich, FRG, September 10-14, 1984. Lütjering, G; Zwicker, U.; and Bunk, W.; eds. 2, 1111 1118.

[34] Shoesmith, D.W. and King, F. 1999. The Effects of Gamma Radiation on the Corrosion of Candidate Materials for the Fabrication of Nuclear Waste Packages. AECL-1 1999. Pinawa, Manitoba, Canada: Atomic Energy of Canada Limited.

[35] Cotton, J.B. 1967. "The Role of Palladium in Enhancing Corrosion Resistance of Titanium." Platinum Metals Review, ll (2), 50-52.

[36] Satoh, K.; Shimogori, K.; and Kamikubo, F. 1987. "The Crevice Corrosion Resistance of Some Titanium Materials: A Review of the Beneficial Effects of Palladium." Platinum Metals Review, 3l, (3), 115-121.

[37] Sedriks, A.J.; Green, J.A.S.; and Novak, D.L. 1972. "Electrochemical Behavior of Ti-Ni Alloys in Acidic Chloride

Solutions." Corrosion, 28, (4), 137-142.

[38] Schutz, R.W. and M. Xiao. 1994. Development of Practical Guidelines for Titanium in Alkaline Peroxide Bleach Solutions. Proceedings of the International Conference on Pulp Bleaching, 153-157.

[39] McKay, P. 1987. "Crevice-Corrosion Kinetics on Titanium and a Ti-Ni-Mo Alloy in Chloride Solutions at Elevated Temperature." Corrosion Chemistry Within Pits, Crevices, and Cracks, Proceedings of a Conference held at Teddington, Middlesex, October 1-3, 1984. Turnbull, A., ed. Paper 7, 107-128.

[40] Van der Lingen, E. and de Villiers Steyn, H. 1994. "The Potential of Ruthenium as an Alloying Element in Titanium." Titanium 1994, Products and Applications, Proceedings of the Technical Program from the 1994 International Conference. Pages 450-461.

[41] Glass, R.S. 1983. "Effect of Intermetallic $\mathrm{Ti}_{2} \mathrm{Ni}$ on the Electrochemistry of TiCode-12 in Hydrochloric Acid." Electrochimica Acta, 28, (11), 1507-1513.

[42] Kidoh, T. and Tsujikawa, S. 1989. "Effects of Ni and Mo on Critical Conditions for Crevice Corrosion of Low Alloy . Titanium." Journal of Iron and Steel Institute of Japan, 75 (8), 96-101.

[43] Sedriks, A.J. 1975. "Corrosion Resistance of Titanium-Ruthenium Alloys." Corrosion, 31, (2), 60-65. [Houston, Texas: National Association of Corrosion Engineers].

[44] CRWMS M\&O 2000. Review of the Expected Behavior of Alpha Titanium Alloys Under Yucca Mountain Conditions.

TDR-EBS-MD-000015 REV 00. Las Vegas, Nevada: CRWMS M\&O. ACC: MOL.20010108.0011.

[45] Hubler; G.K. and McCafferty, E. 1980. "The Corrosion Behaviour and Rutherford Back-Scattering Analysis of Palladium-Implanted Titanium." Corrosion Science, 20, 103-116.

[46] Armstrong, R.D.; Firman, R.E.; and Thirsk, H.R. 1973. "Ring-Disc Studies of .Titanium-Palladium Alloy Corrosion." Corrosion Science, 13, 409-420. (New York, New York): Pergamon Press.

[47] Tun, Z.; Noel, J.J.; and Shoesmith, D.W. 1999. "Electrochemical Modification of the Passive Oxide Layer on a Ti Film Observed by In Situ Neutron Reflectometry." Journal of The Electrochemical Society, 146," (3), 988-994. (New York, New York): The Electrochemical Society.

[48] Pyun, S-I and Yoon, Y-G 1996. "Hydrogen Transport Through $\mathrm{TiO}_{2}$ Film Prepared by Plasma Enhanced Chemical Vapour Deposition (PECVD) Method." Hydrogen Effects in Materials, (Proceedings of the Fifth International Conference on the Effect of Hydrogen on the Behavior of Materials, Moran, Wyoming, September 11-14, 1994). Thompson, A.W. and Moody, N.R., eds., 261-269.

[49] Noël, J.J.; Bailey, M.G.; Crosthwaite, J.P.; Ikeda, B.M.; Ryan, S.R.; and Shoesmith, D.W. 1996. Hydrogen Absorption by Grade-2 Titanium. AECL-11608. Pinawa, Manitoba, Canada: Atomic Energy of Canada Limited, Whiteshell Laboratories.

[50] Schutz, R.W. and Xiao, M. 1993. "Optimized Lean-Pd Titanium Alloys for Aggressive Reducing Acid and Halide Service Environments." Corrosion Control for Low-Cost Reliability, Preceedings, I2th International Corrosion Congress, [Houston, Texas, September 19-24, 1993]. 3A, 1213-1225.

[51] Fukuzuka, T.; Shimogori, K.; and Satoh, H. 1980. "Role of Palladium in Hydrogen Absorption of Ti-Pd Alloy." Titanium '80, Science and Technology: Proceedings of the Fourth International Conference on Titanium. Kyoto, Japan, May 19-20, 1980. 2695-2703.

[52] Shoesmith, D.W.; Hocking, W.H.; Ikeda, B.M.; King, F.; Noël, J.J.; and Sunder, S. 1997. "Application of Electrochemical Methods in the Development of Models for Fuel Dissolution and Container Corrosion Under Nuclear Waste Disposal Conditions." Canadian Journal of Chemistry, 75 (11), 1566-1584.

[53] Noël, J.J. 1999. The Electrochemistry of Titanium Corrosion. Ph.D. Dissertation. Winnipeg, Manitoba, Canada:

[54] Ikeda, B.M. and Quinn, M.J. 1998. Hydrogen Assisted Cracking of Grade-16 Titanium: A Preliminary Examination of Behaviour at Room Temperature. 06819-REP-01200-0039 R00. Toronto, Ontario, Canada: Ontario Hydro.

[55] Ikeda, B.M. and Quinn, M.J. 1998. A Preliminary Examination of the Effects of Hydrogen on the Behaviour of Grade16 Titanium at Room Temperature. 06819-REP-01200-0078-R00. Toronto, Ontario, Canada: Ontario Hydro.

[56] Takekawa, T., Data for Japanese Society of Titanium, Oct. 15th, 1973

[57] Takamura, A. and Yamagata, T. 1967. "Titanium, Zirconium." 15 (8), 192. 
[58] Watanabe, T.; Shindo, T.; and Naito, H. 1988. "Effect of Iron Content on the Breakdown Potential for Pitting of Titanium in NaCl Solutions." Sixth World Conference on Titanium: Cannes, June 6-9, 1988. Lacombe, P.; Tricot, R.; and Beranger, G., eds. $I V, 1735-1740$.

[59] Cotton, J.B. 1970. "Using Titanium in the Chemical Plant." Chemical Engineering Progress, 66, (10), 57-62.

[60] Covington, L.C. and Schutz, R.W. 1981a. "Effects of Iron on the Corrosion Resistance of Titanium." Industrial Applications of Titanium and Zirconium, A Symposium held in New Orleans, Louisiana, 15-17 October, 1979. Kleefisch, E.W., ed. ASTM Special Technical Publication 728, 163-180.

[61] Schutz, R.W.; Grauman, J.S.; and Hall, J.A. 1985. "Effect of Solid Solution Iron on the Corrosion Behaviour of Titanium." Titanium, Science and Technology: Proceedings of the Fifth International Conference on Titanium, CongressCenter, Munich, FRG, September 10-14, 1984. Lutjering, G.; Zwickler, U.; and Bunk, W., eds. 4, 2617-2624.

[62] Ikeda, B.M.; Styles, R.C.; Bailey, M.G.; and Shoesmith, D.W. 1994. "The Effect of Material Purity on Crevice Corrosion of Titanium in $\mathrm{NaCl}$ Solution." Proceedings of the Symposium on Compatibility of Biomedical Implants, (San Francisco, California, 1994). Kovacs, P. and Istephanous, N.S., eds. Volume 94-15, 368-380.

[63] Ruppen, J.A.; Diegle, R.B.; Glass, R.S.; and Headley, T.J. 1983. "Some Effects of Microstructure and Chemistry on Corrosion and Hydrogen Embrittlement of TiCode-12." Scientific Basis for Nuclear Waste Management VI, Symposium held November 1-4, 1982, Boston, Massachusetts. Brookins, D.G., ed. 15, 685-693.

[64] Wu, J.B.C. 1985. "Effect of Iron Content on Hydrogen Absorption and Passivity Breakdown of Commercially Pure Titanium in Aqueous Solutions." Titanium, Science and Technology, Proceedings of the Fifth International Conference on Titanium, Congress-Center, Munich, FRG, September 10-14, 1984. Lutjering, G.; Zwickler, U.; and Bunk, W., eds. 4, 2595-2602.

[65] Wang, Z.W.; Briant, C.L.; and Kumar, K.S. 1999. "Electrochemical, Galvanic, and Mechanical Responses of Grade 2 Titanium in $6 \%$ Sodium Chloride Solution." Corrosion, 55, (2), 128-138.

[66] Hall, J.A.; Banerjee, D.; and Wardlaw, T.L. 1985. "The Relationships of Structure and Corrosion Behavior of Ti0.3Mo-0.8Ni (TiCode-12)." Titanium, Science and Technology: Proceedings of the Fifth International Conference on Titanium, Munich, Germany, September 10-14, 1984. Lutjering, G.; Zwicker, U.; and Bunk, W., eds. 4, 2603-2610.

[67] Blackwood, D.J.; Peter, L.M.; and Williams, D.E. 1988. "Stability and Open Circuit Breakdown of the Passive Oxide Film on Titanium." Electrochimica Acta, 33, (8), 1143-1149.

[68] Reclaru, L. and Meyer, J.-M. 1998. "Effects of Fluorides on Titanium and Other Dental Alloys in . Dentistry." Biomaterials, 19,.85-92.

[69] Thomas, D.E. and Bomberger, H.B. 1983. "The Effects of Chlorides and Fluorides on Titanium Alloys in Simulated Scrubber. Environments." Materials Performance, Vol. 22, National Association of Corrosion Engineers. Houston, Texas, 29-36.

[70] Hua, F.; Mon, K.; Pasupathi, V.; Gordon, G.; and Shoesmith, D. 2004. "Corrosion of Ti 7 and Other Ti Alloys in Nuclear Waste Repository Environments - A Review." Corrosion/2004, 59th Annual Conference \& Exposition, March 28April 1, 2004, New Orleans. Paper No. 04689. Houston, Texas: NACE International.

[71] Baez, V.B.; Graves, J.E.; and Pletcher, D. 1992. "The Reduction of Oxygen on Titanium Oxide Electrodes." Journal of Electroanalytical Chemistry, 340, 273-286. Lausanne, (Switzerland): Elsevier Sequoia S.A.

[72] Schutz, R.W. 1986. "Titanium." Process Industries Corrosion. 503-527.

[73] Phillips, I.I.; Poole, P.; and Shreir, L.L. 1974. "Hydride Formation During Cathodic Polarization of Ti-II. Effect of Temperature and $\mathrm{pH}$ of Solution on Hydride Growth." Corrosion Science, 14, 533-542.

[74] Lunde, L. and Nyborg, R. 1993. "Hydrogen Absorption of Titanium Alloys During Cathodic Polarization." Engineering Solutions to Industrial Corrosion Problems, Sandefjord, Norway, 7-9 June 1993. Paper No.5, NACE, Houston, Texas.

[75] Covington, L.C. and Schutz, R.W. 1981b. "Resistance of Titanium to Atmospheric Corrosion." Corrosion 81, International Corrosion Forum, April 6-10, 1981, Toronto, Ontario, Canada. Pages 113/1-113/7.

[76] Nakamura, T.; Hirohata, Y.; and Hino, T. 1998. "Prevention of Hydrogen Absorption by Surface Oxidation for Ti6A1-4V Alloy with Low Activation Property." Journal of the Vacuum Society of Japan, 41, (3), 324-327. Tokyo, Japan: The Vacuum Society of Japan.

[77] Mattsson, H. and Olefjord, I. 1990. "Analysis of Oxide Formed on Ti During Exposure in Bentonite Clay-I. The Oxide Growth." Werkstoffe und Corrosion, 4I, (7), 383-390.

[78] Mattsson, H.; Li, C.; and Olefjord, I. 1990. "Analysis of Oxide Formed on Ti During Exposure in Bentonite Clay - II. The Structure of the Oxide." Werkstoffe und Korrosion, 4I, (10), 578-584.

[79] BSC (Bechtel SAIC Company) 2004. General Corrosion and Localized Corrosion of the Drip Shield. ANL-EBS-MD000004, Rev. 02. Las Vegas, Nevada: Bechtel SAIC Company.

[80] Shoesmith, D.W.; Hardie, D.; Ikeda, B.M.; and Noel, J.J. 1997. Hydrogen Absorption and the Lifetime Performance of Titanium Waste Containers. AECL-11770. Pinawa, Manitoba, Canada: Atomic Energy of Canada Limited. 
[81] Schutz, R.W. 1988. "Titanium Alloy Crevice Corrosion: Influencing Factors and Methods of Prevention." Proceedings of the Sixth World Conference on Titanium, Cannes, June 6-9, 1988 . Lacombe, P.; Tricot, R.; and Beranger, G., eds. IV, 1917-1922.

[82]Shibata, T. and Zhu, Y.-C. 1995. "The Effect of Film Formation Conditions on the Structure and Composition of Anodic Oxide Films on Titanium." Corrosion Science, 37, (2), 253-270. [New York, New York]: Pergamon Press.

[83] Gilbert, J.L. and Jacobs, J.J. 1997. "The Mechanical and Electrochemical Processes Associated with Taper Fretting Crevice Corrosion: A Review." Modularity of Orthopedic Implants. Marlowe, D.E.; Parr, J.E.; and Mayor, M.B., eds. ASTM STP 1301. Pages 45-59. (West Conshohocken, Pennsylvania): American Society for Testing and Materials.

[84] Harrar, J.E.; Carley, J.F.; Isherwood, W.F.; and Raber, E. 1990. Report of the Committee to Review the Use of J-13 Well Water in Nevada Nuclear.Waste Storage Investigations. UCID-21867. Livermore, California: Lawrence Livermore National Laboratory. ACC: NNA.19910131.0274.

[85] Cheng, T-P.; Lee, J-T.; and Tsai, W-T. 1993. "Galvanic Corrosion of Titanium-Coupled Aluminum Bronze." Materials Chemistry and Physics, 36, 156-160.

[86] Shifler, D.A.; Melton, D.; and Hack, H.P. 1997. "New Techniques for Galvanic Corrosion Prevention in Piping Systems." Proceedings of the 1997 Tri-Service Conference on Corrosion, Wrightsville Beach, North Carolina, November 17-21, 1997, Naval Surface Warfare Center--Carderock Division. 1, 1-22.

[87] Hack, H. P. and Taylor, D., Evaluation of Galvanic Corrosion", ASM International 1987. Corrosion. Volume 13 of Metals Handbook. 9th Edition. Metals Park, Ohio: ASM International, p. 235.

[88] Hodgkiess, T.; Maciver, A.; and Chong, P.Y. 1987. "Galvanic Studies Related to the Use in Desalination Plant of Corrosion-Resistant Materials." Desalination, 66, 147-170. New York, New York: Elsevier.

[89] Fukuzuka, T.; Shimogori, K.; Satoh, H.; Kamikubo, F.; and Hiroaki, H. 1979. "Prevention of Hydrogen Absorption in Titanium by Surface Oxidation." Boshoku Gijutsu, 28, 409-496.

[90] Clarke, C.F.; Hardie, D.; and Ikeda, B.M. 1995. Hydrogen Induced Cracking of Grade-2 Titanium. AECL-11284. Pinawa, Manitoba, Canada: Whiteshell Laboratories.

[91] Clarke, C.F.; Hardie, D.; and Ikeda, B.M. 1997. "Hydrogen-Induced Cracking of Commercial Purity Titanium." Corrosion Science, 39 (9), 1545-1559.

[92] Shoesmith,: D.W.; Ikeda, B.M.; Bailey, M.G.; Quinn, M.J.; and LeNeveu, D.M. 1995. A Model for Predicting the Lifetimes of Grade-2 Titanium Nuclear Waste Containers. AECL-10973. Pinawa, Manitoba,Canada: Atomic Energy of Canada Limited.

[93] Sorensen, N.R. 1990. "Laboratory Studies of the Corrosion and Mechanical Properties of Titanium Grade-12 Under WIPP Repository Conditions." Corrosion of Nuclear Fuel Waste Containers, Proceedings of a Workshop. Winnipeg, Manitoba, 1988 February 9-10. Shoesmith, D.W., ed. AECL-10121,29-44. Winnipeg, Manitoba, Canada: Atomic Energy of Canada Limited.

[94] Kitayama, S.; Shida, Y.; and Oshiyama, M. 1990. "Development of New Crevice Corrosion Resistant Ti Alloys." Sumitomo Search, 4I, 23-32.

[95] Gordon, G. 1999. "Stress Corrosion Cracking (SCC) and Hydrogen Induced Cracking (HIC): Modeling and Experimental Program Status", presented at CLST Appendix 7 Meeting, Lawrence Livermore National Laboratory, July 7. $8,1999$.

[96]Greene, C.A.; Henry, A.J.; Brossia, C.S.; and Ahn, T.M. 2001. "Evaluation of the Possible Susceptibility of Titanium 7 to Hydrogen Embrittlement in a Geologic Repository Environment." Scientific Basis for Nuclear Waste Management XXIV, Symposium held August 27-31, 2000, Sydney, Australia. Hart, K.P. and Lumpkin, G.R., eds. 663, 515-523. Warrendale, Pennsylvannia: Materials Research Society.

[97] Ikeda, B.M.; Quinn, M.J.; Noël, J.J.; and Shoesmith, D.W. 2000. "The Hydrogen-Induced Cracking and Hydrogen Absorption Behaviour of Grade-16 Titanium." Environmentally Induced Cracking of Metals, Proceedings of the International Symposium, August 20-23, 2000, Ottawa, Ontario, Canada. Elboujdaini, M.; Ghali, E. and Zheng, W.; eds., 235-248.

[98] BSC (Bechtel SAIC Company) 2004. Hydrogen-Induced Cracking of Drip Shield. ANL-EBS-MD-000006, Rev. 02. Las Vegas, Nevada: Bechtel SAIC Company.

[99] Kitayama, S.; Shida, Y.; Ueda, M.; and Kudo, T. 1992. "Effect of Small Pd Addition on the Corrosion Resistance of TI and TI Alloys in Severe Gas and Oil Environment." Corrosion 92. Paper No. 52. NACE.

[100] Hardie, D. and Ouyang, S. 1999. "Effect of Hydrogen and Strain Rate Upon the Ductility of Mill-Annealed Ti6Al4V." Corrosion Science, $4 I$ (1), 155-177.

[101] Foroulis, Z.A. 1980. "Factors Influencing Absorption of Hydrogen in Titanium from Aqueous Electrolytic Solutions." [Titanium '80. Science and Technology, Proceedings of the 4th International Conference on Titanium]. [4], $2705-2711$. [Warrendale, Pennsylvania: Metallurgical Society of AIME].

[102] Watanabe, T.; Naito, H.; Suzuki, K.; and Nakamura, Y. 1986. "Hydrogen Absorption of Commercially Pure Titanium in the Solution System NaCl-HCl." Tetsu to Hagane, 72, 136-141. 
[103] Weast, R.C., ed. 1985. CRC Handbook of Chemistry and Physics. 66th Edition. Boca Raton, Florida: CRC Press.

[104 ] BSC 2005. Screening of Features, Events, and Processes in Drip Shield and Waste Package Degradation. ANLEBS-PA-000002 REV 05. Las Vegas, Nevada: Bechtel SAIC Company.

[105] Hua, F.; Mon, K.; Pasupathi, V.; Gordon, G.; and Shoesmith, D. 2005. "Modeling the Hydrogen-Induced Cracking of of Titanium Alloys in Nuclear Waste Repository Environments." Journal of Metals, January 2005, 20-26. 